\title{
A Test of Core Vote Theories: The British Conservatives, 1997-2005
}

\author{
JANE GREEN*
}

The British Conservative party during 1997-2005 appeared to support the view that parties react to defeat by energizing their core vote base. Using a series of spatial and salience-based definitions of the core vote, combined with elite interviews with William Hague, Iain Duncan Smith and Michael Howard, the three Conservative leaders between 1997 and 2005, empirical evidence in support and also refutation of the core vote critique is evaluated here. The analyses suggest that Conservative issue strategies between 1997 and 2005 were chosen on grounds of spatial proximity and public perceptions of issue ownership, and that an appeal to Conservative voters was consistent with a broader appeal. The implications of this evidence are important for conceptualizing and applying party base explanations in Britain and beyond.

Parties' strategic decisions are often thought to trade between pursuing the support of the majority and satisfying the interests of the base. American presidential candidates reassure their party ticket that the instincts and commitments that won them the nomination will be delivered in office, but appeal to the wider electorate on a more moderate platform. In the 2004 US presidential election, a strongly aligned electorate enabled George W. Bush to muster a 'Get Out the Vote' campaign, rather than persuade independents or win over wavering Democrats. The dominance of ideas about appealing to the base in the United States is such that the concepts have naturally been applied to other countries. As in the United States, divergent party positions are explained in West European party systems, such as Britain, France and Norway, by the ideological nature of a party's base; its partisans. ${ }^{1}$ These voters, it is argued, provide a strong incentive pulling parties away from the Downsian median voter equilibrium position. ${ }^{2}$

The idea that electoral constituencies diverge ideologically is uncontroversial within the cleavage view of politics whereby party-voter representation operates via meaningful

* School of Social Sciences, University of Manchester (email: jane.green@manchester.ac.uk). The author wishes to thank Geoffrey Evans, all those who assisted with arranging or providing interviews with Conservative party leaders, and also Laura Stoker, Caitlin Milazzo, the Editors of the Journal and the anonymous referees for their invaluable comments on earlier drafts.

1 See James Adams and Samuel Merrill, 'Modeling Party Strategies and Policy Representation in Multiparty Elections: Why Are Strategies so Extreme?' American Journal of Political Science, 43 (1999), 765-91; James Adams, Party Competition and Responsible Party Government: A Theory of Spatial Competition Based upon Insights from Behavioral Voting Research (Ann Arbor: University of Michigan Press, 2001); James Adams, 'A Theory of Spatial Competition with Biased Voters: Party Policies Viewed Temporally and Comparatively', British Journal of Political Science, 31 (2001), 121-58; James Adams, Samuel Merrill and Bernard Grofman, A Unified Theory of Party Competition: A Cross-National Analysis Integrating Spatial and Behavioral Factors (New York: Cambridge University Press, 2005); and Norman Schofield, 'A Valence Model of Political Competition in Britain: 1992-1997', Electoral Studies, 24 (2005), 347-70.

2 Anthony Downs, An Economic Theory of Democracy (New York: Harper \& Row, 1957). 
sociological cleavages. ${ }^{3}$ Party base arguments also find support in intra-party studies pointing to purist activist motivations, policy-seeking politicians, and party democratization and member control over policy making. ${ }^{4}$ Kitschelt explains, "A party may desire to subordinate its vote or office seeking to the higher goal of policy'. ${ }^{5}$ Purist politicians may also believe a policy-seeking strategy will maximize votes, given the electoral demand for programmatic politics and the potential for preference and agenda shaping. ${ }^{6}$ Therefore, parties face incentives to appeal to the base due to several possible factors: elite ideological commitments or policy-seeking motivations, member influence over policy, and demands to gain the electoral support of partisans or existing voters derived from distinctive electoral constituencies. These base strategies are manifested in appeals designed to mobilize existing voters rather than persuade new ones. Such incentives are argued to be particularly strong for defeated or unpopular parties for whom the core vote is the only likely available vote in an election. ${ }^{7}$ Thus, as the British Labour party appeared to be facing relegation to the opposition in the general election of 2010 , its election campaign was described as an appeal to Labour's core vote. ${ }^{8}$

The core vote explanation has been most widely applied to the British Conservatives in opposition between 1997 and 2005. Following the landslide victory of the Labour party in 1997, the Conservatives failed to move beyond support of around 30 per cent under the leaderships of William Hague (June 1997-June 2001), Iain Duncan Smith (September 2001-November 2003) and Michael Howard (November 2003-December 2005). The party's 2001 and 2005 election campaigns were widely depicted as focusing on issues of interest to core Conservative voters rather than the majority, and the policies depicted as a lurch to the right. ${ }^{9}$

${ }^{3}$ Seymour M. Lipset and Stein Rokkan, 'Cleavage Structures, Party Systems, and Voter Alignments: An Introduction', in Seymour M. Lipset and Stein Rokkan, eds, Party Systems and Voter Alignments (New York: The Free Press, 1967), pp. 1-64.

${ }^{4}$ Albert O. Hirschman, Exit, Voice, and Loyalty: Responses to Decline in Firms, Organizations, and States (Cambridge, Mass.: Harvard University Press, 1970); John D. May, 'Opinion Structure of Political Parties: The Special Law of Curvinlear Disparity', Political Studies, 21 (1972), 135-151; David B. Robertson, A Theory of Party Competition (London: New York: John Wiley, 1976); Iain McLean, Dealing in Votes: Interactions between Politicians and Voters in Britain and the USA (Oxford: M. Robertson, 1982); John H. Aldrich, 'A Downsian Spatial Model with Party Activism', American Political Science Review, 77 (1983), 974-90; Henry W. Chappell and William R. Keech, 'Policy Motivation and Party Differences in a Dynamic Spatial Model of Party Competition', American Political Science Review, 80 (1986), 881-99; Herbert Kitschelt, The Logics of Party Formation: Ecological Politics in Belgium and West Germany (Ithaca, N.Y.: Cornell University Press, 1989); Herbert Kitschelt, The Transformation of European Social Democracy, Cambridge Studies in Comparative Politics (Cambridge: Cambridge University Press, 1994); George Tsebelis, Nested Games: Rational Choice in Comparative Politics, California Series on Social Choice and Political Economy (Berkeley: University of California Press, 1990); Kaare Strøm, 'A Behavioural Theory of Competitive Political Parties', American Journal of Political Science, 34 (1990), 565-98.

${ }^{5}$ Kitschelt, 'The Transformation of European Social Democracy', p. 116.

${ }^{6}$ Patrick Dunleavy and Hugh Ward, 'Exogenous Voter Preferences and Parties with State Power: Some Internal Problems of Economic Theories of Party Competition', British Journal of Political Science, 11 (1981), 351-80; Kitschelt, 'The Transformation of European Social Democracy'; Michael Laver, 'Policy and the Dynamics of Political Competition', American Political Science Review, 99 (2005), 263-81.

${ }^{7}$ Robertson, 'A Theory of Party Competition'.

${ }^{8}$ Steven Fielding, 'Labour's Campaign: Things Can Only Get ... Worse', in Andrew Geddes and Jonathon Tonge, eds, The UK Votes: The General Election of 2010 (Oxford: Oxford University Press, 2010), pp. 653-66.

9 David Butler and Dennis Kavanagh, The British General Election of 2001 (Basingstoke, Hants.: Palgrave, 2001); Pippa Norris, 'Apathetic Landslide: The 2001 British General Election', Parliamentary Affairs, 54 (2001), 565-89; Daniel Collings and Anthony Seldon, 'Conservatives in Opposition', 
A focus on the party's vote base seems to have forced the Conservative party away from a more moderate agenda, delaying a process of recovery. Using this interpretation, David Cameron's modernization strategy (leader from December 2005) was a marked departure. Thus, the British Conservatives in opposition, prior to 2006, appear to confirm the mobilization-versus-persuasion trade-off, the incentive to pursue divergent policies, rather than Downsian median voter convergence, ${ }^{10}$ and a rejection of office-seeking incentives that would demand a party reach out beyond a minimal level of support. This case study provides the ideal case to examine core vote explanations.

Existing interpretations of the British Conservatives in opposition are based upon untested assumptions about the nature of the Conservative core vote and about the party base more generally. They are rooted in the beliefs that (a) all electorates remain strongly divided along ideological dimensions, (b) candidates have similar incentives to play to the base in countries outside the United States (where primaries do not provide such obvious incentives to do so), and (c) unpopular parties will continue to pursue strategies that limit their opportunities for electoral recovery. Existing interpretations about the Conservative party also lack force when placed in the context of the opposition leadership of David Cameron prior to the 2010 general election. Cameron sought to change the Conservative party's image by focusing on new issues and by downplaying traditional issues such as Europe, taxation, immigration, law and order. ${ }^{11} \mathrm{He}$ claimed to have repositioned the party in the centre ground. ${ }^{12}$ His ability to build on the core Conservative vote base, rather than lose large segments of support, suggests that a new issue agenda may be consistent with retaining the loyalty of this traditional electoral base. No one has studied the Conservative base with a view to testing these assumptions, and no testable operational definitions about the nature of the party base have been generated. ${ }^{13}$

This article conceptualizes expectations about a party's core voters - relating first to spatial divergence, then to divergence in issue agendas - and tests these expectations using available survey data and polling data, as well as using elite data obtained by interviews with three Conservative party leaders. It aims to contribute by conceptualization and in breadth of analysis, so as to evaluate claims and counter-claims systematically in support of, and in refutation of, the core vote account applied to the example of the Conservative party in opposition. Thereafter, this idea is extended towards an alternative theoretical

\footnotetext{
(F'note continued)

Parliamentary Affairs, 54 (2001), 624-37; Richard Kelly, 'Conservatism under Hague: The Fatal Dilemma', Political Quarterly, 72 (2001), 197-203; Mark Garnett and Philip Lynch, 'Bandwagon Blues: The Tory Fightback Fails', Political Quarterly, 73 (2002), 29-37; Mark Garnett and Philip Lynch, The Conservatives in Crisis: The Tories after 1997 (Manchester: Manchester University Press, 2003); Pippa Norris and Joni Lovenduski, 'Why Parties Fail to Learn: Electoral Defeat, Selective Perception and British Party Politics', Party Politics, 10 (2004), 85-104; Anthony Seldon and Peter Snowdon, 'The Conservative Campaign', Parliamentary Affairs, 58 (2005), 725-42.

${ }^{10}$ Downs, 'An Economic Theory of Democracy'.

11 Tim Bale, The Conservative Party from Thatcher to Cameron (Cambridge: Polity Press, 2010), p. 316; Jane Green, 'Strategic Recovery? The Conservatives Under David Cameron', in Andrew Geddes and Jonathan Tonge, eds., Britain Votes 2010, pp. 85-106.

12 'So yes, this is a modern, progressive Conservative manifesto. It is confirmation that this party has changed ... that we have returned to the centre ground of British politics ... and that is where we will stay.' http://www.conservatives.com/News/Speeches/2010/04/David_Cameron_Your_invitation_to_join_ the_Government_of_Britain.aspx (speech at the launch of the Conservative's 2010 election manifesto).

${ }^{1 \overline{3}}$ Robert Rohrschneider, 'Mobilizing versus Chasing: How do Parties Target Voters in Election Campaigns?' Electoral Studies, 21 (2002), 367-82.
} 
explanation of core vote party appeals that appear to defeat vote-winning objectives: namely, parties facing electoral unpopularity are forced into a strategy of promoting a narrow range of their traditional strengths, representing a limited issue domain on which they have a chance of being rated more positively. These traditional issues ('Conservative issues' in this example), are not, however, synonymous with issues of concern only to the electoral base, but are a party's remaining 'best issues' or their perceived 'owned issues'. ${ }^{14}$ These strategies are examples of parties attempting to maximize their vote - rather than just playing to the base - albeit in contexts in which large electoral gains are unlikely. Parsing out the conceptual confusion between 'core vote' and 'best' or 'owned' issues offers insights into a more plausible explanation of the strategies of relatively unpopular parties. This has occurred in Britain, and may also have happened in a range of comparative contexts in which party base explanations are commonly applied.

\section{A CORE VOTE APPEAL: CONCEPTUAL DISTINCTIONS}

Despite the important literature on the influence on party policies of partisans, ${ }^{15}$ core voters, ${ }^{16}$ hard core voters, ${ }^{17}$ activists ${ }^{18}$ and party members, ${ }^{19}$ scholars have not coalesced around one definition of the party base. One reason may be the assumption that party voters, partisans, activists, members, etc. share issue agendas and issue positions, without a need for distinction. This would overlook other evidence, however, to suggest that intraparty groups are different in important ways, ${ }^{20}$ that party elites are often more polarized than their members ${ }^{21}$ and that a party's core constituencies will change over time.

Core vote interpretations of Conservative strategy and theories of partisan-based incentives consider the influence of individuals who regularly vote for the party, the 'normal vote' ${ }^{22}$ or those individuals who identify with the party. ${ }^{23}$ These groups do not

14 John R. Petrocik, 'Issue Ownership in Presidential Elections, with a 1980 Case Study', American Journal of Political Science, 40 (1996), 825-50; John R. Petrocik, William L. Benoit, and Glenn J. Hansen, 'Issue Ownership and Presidential Campaigning, 1952-2000', Political Science Quarterly, 118 (2003), 599-626.

15 Adams and Merrill, 'Modeling Party Strategies and Policy Representation in Multiparty Elections'; Adams, 'Party Competition and Responsible Party Government'; Adams, 'A Theory of Spatial Competition with Biased Voters'; Adams, Merrill and Grofman, 'A Unified Theory of Party Competition'; Schofield, 'A Valence Model of Political Competition in Britain'.

16 For example, Butler and Kavanagh, The British General Election of 2001; Norris and Lovenduski, 'Why Parties Fail to Learn'; Collings and Seldon, 'Conservatives in Opposition'; Seldon and Snowdon, 'The Conservative Campaign'.

17 Charles Cook, 'Both Parties Are Missing 'Bold Colors' to Appeal to their Bases in 1998', Roll Call Monthly, 7 (December 1997).

18 Aldrich, 'A Downsian Spatial Model with Party Activism'.

19 Tsebelis, Nested Games.

${ }^{20}$ May, 'Opinion Structure of Political Parties'; Pippa Norris, 'May's Law of Curvilinear Disparity Revisited: Leaders, Officers, Members and Voters in British Political Parties', Party Politics, 1 (1995), $29-47$.

21 Russell Dalton, 'Political Parties and Political Representation: Party Supporters and Party Elites in Nine Nations', Comparative Political Studies, 18 (1985), 267-99.

${ }^{22}$ Philip E. Converse, 'The Concept of a Normal Vote', in Angus Campbell, Phillip E. Converse, Warren E. Miller and Donald E. Stokes, eds, Elections and the Political Order (New York: Wiley and Sons, 1966), pp. 9-39.

${ }^{23}$ Morris Fiorina, 'What Happened to the Median Voter?' (unpublished paper for the MIT Conference on Parties and Congress, Cambridge, Mass., 1999); Ron Johnston and Charles Pattie, 'Representative 
represent the ginger interests inside a party but a party's natural electoral base. With respect to the British Conservatives, the group was singled out as those to whom the party was appealing constituted the core vote. ${ }^{24}$ These were the \pm 30 per cent of voters for whom the Conservatives under William Hague, Iain Duncan-Smith and Michael Howard were still the party of choice. The analyses in this article, and their implications, are therefore restricted to respondents intending to vote Conservative, or those identifying with the Conservatives, between 1997 and 2005, according to the available data. ${ }^{25}$

The first step must be to specify expectations about what a core vote appeal comprises and next to develop clear expectations about the issue positions and agendas of core Conservative voters. This section therefore asks: what has to hold to be true if the Conservative party could be pulled away from a moderate issue agenda, or pulled towards extreme policy positions, for the party still to be on the same issue agenda and in close proximity to its existing vote base?

A party could take policy positions closer to the mean position of its core voters relative to the mean position of other voters. This expectation would lead to two necessary conditions:

1. The mean core Conservative party voter position must be to the right of the mean positions of other potential voters; and

2. The mean position of core Conservative voters must be to the right of the Conservative party, or alternatively closer to the Conservative party's positions relative to the mean positions of other voters.

It would not make sense, for example, to argue that the Conservative party lurched to the right, to appeal only to its base, if its base were not more right-wing than the average voter or voters of other parties. Also, if the Conservative policy position is closer to other voters, the party could not be argued to have adopted policy positions solely to energize its core vote.

For the purposes of the analysis, the positions of the party and its voters are examined predominantly at time $t$, in relation to the election period, but change over time is also considered subsequently. Parties may learn lessons from election campaigns and alter their positions for the next election, and so we should examine the responsiveness of parties to their voters over time. ${ }^{26}$

In relation to issue salience, for a core vote appeal to be supported, the Conservative party would need to have emphasized issues to which its core voters gave higher priority.

(F'note continued)

Democracy and Electoral Geography', in John A. Agnew, Katharyne Mitchell and Gerard Toal (Gearóid O'Tuathail), eds, A Companion to Political Geography (Oxford: Blackwell Publishing, 2003); Susan C. Stokes, 'Reverse Accountability: A Formal Model of Machine Politics with Evidence from Argentina', American Political Science Review, 99 (2005), 315-25; Gary C. Cox, 'Swing Voters, Core Voters and Distributive Politics' (paper presented at the Yale Conference on Representation and Popular Rule, 2006).

24 Butler and Kavanagh, 'The British General Election of 2001'; Norris, 'Apathetic Landslide'; Collings and Seldon, 'Conservatives in Opposition'; Kelly, 'Conservatism under Hague'; Garnett and Lynch, 'Bandwagon Blues'; Garnett and Lynch, The Conservatives in Crisis; Norris and Lovenduski, 'Why Parties Fail to Learn'; Seldon and Snowdon, 'The Conservative Campaign'.

${ }^{25}$ The association between Conservative party identification and vote intention is very high. The proportions of Conservative identifiers voting Conservative were 95 per cent, 87 per cent and 83 per cent in 1997, 2001 and 2005, respectively (source: 1997, 2001, 2005 BES cross-sections).

${ }^{26}$ Zeynep Somer-Topcu, 'Timely Decisions: The Effects of Past National Elections on Party Policy Change', Journal of Politics, 71 (2009), 238-48. 
If the party campaigns on an issue its voters care about, but other voters also care about that issue, the party cannot be appealing to core voters alone. A party could emphasize issues on which core voters were in closer proximity and to which core voters gave higher priority, but avoid issues that other voters cared most about. These expectations point to one necessary condition relating to the degree of issue salience divergence among party voters, namely:

3. The issues prioritized by Conservative core voters must be distinct to the issues prioritized by other voters.

Therefore, the empirical questions evaluated in this article concern the degree to which core Conservative voters shared different issue positions and different issue priorities, and the degree to which those issue positions were in closer proximity to the positions taken by the Conservative party. We would not expect any party to fail to address issues its voters care about, and so the primary questions relate to emphases and positions to which only Conservative core voters attach importance or are in proximity, avoiding issues to which other voters attach importance or are closest.

DATA AND MEASURES: VOTER AND PARTY ISSUE POSITIONS AND VOTER ISSUE IMPORTANCE

Party policy positions are commonly measured using elite surveys, content analysis of party manifestos, expert surveys or voter's perceptions of party policy. This article reviews available evidence from all four sources.

Elite surveys of policy self-placements have been conducted using the British Representation Study (BRS) in 1997, 2001 and 2005 (and the British Candidate Study, BCS, in 1992). For the time periods in question - the 2001 and 2005 general elections there are expert surveys in $1997^{27}$ and in $2002-03^{28}$ but data are not available for 2005 . Manifesto content analyses have been undertaken for the whole period by the Comparative Manifestos Project (CMP). ${ }^{29}$ The British Election Study (BES) surveys provide comparable voter self-placements and perceived party placements over several election studies between 1987 and $2001^{30}$ for the following issues: taxation and public spending, inflation/unemployment, whether to nationalize or privatize industries, and whether wealth should be redistributed. In 1992 and 1997 the cross-sections included a question on European integration, and this was repeated in the 1992-97 and 1997-2001 panel studies, providing post-election estimates in 2001, and new questions on the subject of Europe were asked in the 2001 and 2005 cross-sections. ${ }^{31}$ Data from the 2005 British Social Attitudes survey and Ipsos-MORI provide estimates of attitudes towards the relevant issues of asylum, race relations and immigration.

27 Michael Laver, 'Party Policy in Britain 1997: Results from an Expert Survey', Political Studies, 46 (1998), 336-47.

${ }^{28}$ Kenneth Benoit and Michael Laver, Party Policy in Modern Democracies (London: Routledge Research in Comparative Politics, 2006).

29 Bara has analysed the CMP data for Britain; see Judith Bara, 'The 2005 Manifestos: A Sense of Déja Vu?', Journal of Elections, Public Opinion and Parties, 16 (2006), 265-81.

30 Prior to 1987 , the question wordings of BES policy scales were different, with different end points and often different scales. The 2005 BES omitted some policy questions in earlier cross-sections and panels.

31 In each case, 'don't know' responses are omitted, so that biases are reduced as far as possible, and party position estimates are taken from the overall mean, minimizing assimilation or projection effects. 
The measurement of the issue priorities of voters has received much less attention. There are three available issue importance measures in the British Election Studies (crosssection and panel). Each is, however, prone to the confounding effect of studies taking place during or after elections. There are empirical and theoretical reasons to expect that parties cue their own voters most effectively, ${ }^{32}$ and so asking these questions during election campaigns may pick up a response to party messages, rather than a response by parties to issues prioritized by their base. ${ }^{33}$

The 'what is the single most important election issue?' item in the 2001 BES prompts voters to evaluate what the parties are talking about in the election. ${ }^{34}$ The second item is the 'most important issue facing the country' question in the $2005 \mathrm{BES}$, but again this item is asked following the campaign. The remaining item was asked in the $2001 \mathrm{BES}$ 'rolling thunder study' (daily, throughout the campaign), 'How important is... health/ education/taxation/crime?' on a zero to ten scale where $0=$ not at all important and $10=$ very important. Respondents could choose every issue as important and there is little variation by partisanship. ${ }^{35}$ Ideally, we would like to be able to use a measure of issue importance that runs for prolonged periods, before and after elections.

Ipsos-MORI repeatedly asks a random sample of approximately 1,000 respondents to identify the 'most important issue facing the country today'. The data are monthly and span a long time period that varies by issue, the earliest data point being September 1974. Between January 1999 and December 2007, these data are available at the individual level, with a set of covariates including vote intention. ${ }^{36}$ These data offer ninety-nine time points over an eight-year period - prior to, during and following the election campaigns of 2001 and 2005. Using vote intention (among those certain to vote) and disaggregating by Conservative, Labour, Liberal Democrats, those not intending to vote and undecided respondents (the five largest categories), it is possible to observe variation in mentions of issue salience, through the percentage rating an issue most important. The analysis plots the salience of each issue, over time and by party support, and calculates the Pearson correlation coefficient between salient mentions of the groups. This gives a measure of shared variance in issue salience on a given issue between, for example, Conservatives and Labour supporters, Conservatives and Liberal Democrats, and so on. The mean salience for each issue is also calculated by each subgroup, providing the 'average salience gap'.

The data are first reported with respect to spatial criteria, and then with respect to issue salience.

32 See John Zaller, 'Information, Values, and Opinion', American Political Science Review, 85 (1991), 1215-37; John Zaller The Nature and Origins of Mass Opinion (Cambridge: Cambridge University Press, 1992).

33 Note that this problem also relates to the relationship of issue preferences and concerns to the vote since parties seek to prime voters to cast their votes on favourable party issues.

34 If we took this measure as a proxy for party issue emphasis, the Conservative party's top three issues (in order of emphasis) would be health $>$ Europe $>$ taxation. The Labour party's would be health $>$ education $>$ pensions. The Liberal Democrat's would be health $>$ education $>$ Europe. Overall, the 'most important election issues' were of the order: health, education, Europe, taxation, pensions, crime, economy.

${ }^{35}$ For example, all respondents, by party identification, ranked health between 9.03 and 9.35 on the $0-10$ scale, all ranked taxation between 7.47 and 7.98 , all ranked education between 8.59 and 9.11 , and all ranked crime between 8.62 and 8.93 (total $N=4,304$ ).

36 These data were kindly made available to the author by Dr Roger Mortimore from Ipsos-MORI. 
There is a contradiction between two arguments made about recent British politics: the argument that the Conservatives lost the elections because they appealed to their core vote, moving too far to the right to create 'clear blue water' between themselves and Labour; and the argument that a significant policy depolarization and consensus has come to characterize party ideological positions. ${ }^{37}$ In answer to a regular BES question regarding perceptions of differences between the main parties, ${ }^{38} 85$ per cent answered that there was 'a great deal of difference' in 1987 but by 2001 only 28 per cent answered 'a great deal of difference'; and in 2005, only 23 per cent did so. These data support the depolarization interpretation, and are confirmed by a range of estimates of party policy differences.

The British Representation Studies (1997, 2001 and 2005) asked party elites (candidates and MPs) to place themselves on the tax-spend, nationalization and European Union policy scales, as well as on a left-right scale. Mean values are shown in Table 1 (where $0=$ left or pro-Europe and $10=$ right or Eurosceptic), which reveals a pattern of Conservative elites moving from more right-wing positions in 1997 towards slightly more centrist positions by 2005. Placements for MPs alone showed the same trend across each scale. ${ }^{39}$ The changes on the left-right measure are modest, suggesting that Conservative candidates and MPs still view their party in left and right terms, but on the issue of taxation and public spending, nationalization and even European integration, the selfplacement of Conservative politicians moved further towards the centre point (5) and away from the most right-wing (or Eurosceptic) self-placements at point 10. These data suggest that even among Conservative elites there was some degree of moderation over time, although the party had slightly hardened its Eurosceptic position by 2001, and its position was less hard in 2005 .

The Comparative Manifesto Project (CMP) estimates the left-right positions of the main British parties between 1945 and 2005, revealing a pattern of Labour and Conservative depolarization during the 1990s and 2000s, consistent with the BES question response cited above (the difference between the main parties). By the time of the 1997, 2001 and 2005 general elections, there were minimal policy differences between Labour and the Conservatives, ${ }^{40}$ on a par with those observed in the mid-1950s during the post-war period. This depolarization, subsequent to 1997, is not only due to a gradual movement towards the centre by the British Labour party, but also a shift by the Conservatives away from more Thatcherite policies in the mid to late 1980s. These data give greater support to the depolarization interpretation of British political competition than does the lurch to the right interpretation of the Conservatives. The CMP data also reveal a shift towards a greater

${ }^{37}$ Harold Clarke, David Sanders, Marianne C. Stewart and Paul M. Whiteley, 'Taking the Bloom off New Labour's Rose: Party Choice and Voter Turnout in Britain, 2005', Journal of Elections, Public Opinion and Parties, 16 (2005), 3-36; Jane Green, 'When Voters and Parties Agree: Valence Issues and Party Competition', Political Studies, 55 (2007), 629-55; James Adams, Jane Green and Caitlin Milazzo, 'Has the British Public Depolarized Along with Political Elites? An American Perspective on British Public Opinion', Comparative Political Studies, 45 (forthcoming 2012).

38 'Considering everything the Conservative and Labour parties stand for, would you say there is a great difference between them, some difference between them, or, not much difference between them?'

${ }_{39}$ These were based on large sample sizes in 1997 (approx. 71) but the 2001 obtained smaller Conservative MP samples of around 30. Therefore, the total Conservative samples are reported in Table 1.

${ }^{40}$ Bara, 'The 2005 Manifestos'. 
TA B L 1 Average Self-Placed Policy Positions of Conservative MPs and Candidates, British Representation Studies, 1997, 2001, 2005

\begin{tabular}{lccc}
\hline \hline & 1997 & 2001 & 2005 \\
& Mean (Std. Dev) & Mean (Std. Dev) & Mean (Std. Dev) \\
& $N$ & $N$ & $N$ \\
\hline Left-Right & $7.07(1.57)$ & $7.08(1.26)$ & $6.95(1.26)$ \\
& 282 & 336 & 220 \\
Tax-Spend & $7.87(1.75)$ & $6.66(2.14)$ & $6.53(1.65)$ \\
Nationalization & 273 & 298 & 206 \\
European Integration & $8.88(1.61)$ & $8.12(1.92)$ & - \\
& 285 & 341 & $7.56(2.02)$ \\
& $8.22(2.13)$ & $8.62(1.85)$ & 219 \\
\hline \hline
\end{tabular}

Note: 1-7 left-right scale in 1992, recalibrated to 0-10: Conservatives $7.22(1.47), N=566$. Measures:

Left-right: In politics, people sometimes talk of left and right. Using the following scale, where (0) means left and (10) means right, where would you place yourself? (recalibrated).

Tax-spend: Some people feel that government should put up taxes a lot and spend much more on health and social services (0). Other people feel that government should cut taxes a lot and spend much less on health and social services (10). Using the following scale, where would you place yourself?

Nationalization: Some people feel that government should nationalize many more private companies $(0)$. Other people feel that government should sell off many more nationalized industries (10). Using the following scale, where would you place yourself?

European Integration: Some people feel that Britain should do all it can to unite fully with the European Union (0). Other people feel that Britain should do all it can to protect its independence from the European Union (10). Using the following scale, where would you place yourself?

Source: British Candidate Study 1992 and British Representation Studies 1997 and 2001 available from www.pippanorris.com, downloaded with thanks. British Representation Study 2005 generously provided by Dr Rosie Campbell, Birkbeck College, University of London.

Eurosceptic emphasis by the Conservatives. ${ }^{41}$ On this issue, the manifesto analysis suggests that the Conservatives moved in a Eurosceptic direction following the 1992 election, to its most Eurosceptic position in 2001, then slightly softened their position in 2005.

Using expert surveys, and also disaggregating CMP scores by policy area, Benoit and Laver argue that the change in Conservative left-right position was due, in large part, to major changes in economic policy emphasis. ${ }^{42}$ The timing of questions and the noncomparability of items means that the expert surveys of party positions cannot be compared in a similar way between 1997 and 2005, but Laver reports estimates of the British parties' positions across eight policy issues, and the change between 1989 and 1997. ${ }^{43}$ Between those years, experts judged the Conservatives to have moved significantly towards the centre on economic policy, environmental policy and on social values. ${ }^{44}$

\footnotetext{
41 Ben Clements and John Bartle, 'The European Issue and Party Choice at British General Elections, 1974- 2005', Journal of Public Opinion and Parties, 19 (2009), 377-411.

${ }^{4}$ Kenneth Benoit and Michael Laver, 'Estimating Party Policy Positions: Comparing Expert Surveys and Hand-Coded Content Analysis', Electoral Studies, 26 (2007), 90-107.

43 Laver, 'Party Policy in Britain 1997'.

44 Laver, 'Party Policy in Britain 1997', p. 339.
} 
Another version of the expert survey was conducted in 2002-03 using a 1-20 scale. ${ }^{45}$ Experts placed the Conservatives at 16.4 to Labour's 10.9 on a left-right estimate, 17.6 to Labour's 10.0 on European authority, 15.3 to Labour's 10.0 on taxation and public spending, and 13.8 to Labour's 9.0 on immigration. ${ }^{46}$ These $2002-03$ positions suggest that there were significant differences on European policy between the two main parties, but more modest differences on left-right, tax-spend and even on immigration - an issue argued to have been central to the Conservative's core vote appeal in the 2001 and 2005 elections.

Using voter self-placements and perceived party placements, a range of studies support the observation that the major parties depolarized on the left-right dimension between 1987 and 2005. ${ }^{47}$ The average Conservative party placement moved towards the centre, across a range of measures, but to a more Eurosceptic position on European integration, particularly by $2001 .^{48}$ It appears that on left-right issues, there is mounting evidence to question the core vote critique in relation to estimates of Conservative policy, where there is evidence of party policy depolarization and greater relative policy convergence, but there is the potential for confirmation via the Conservative's increasingly Eurosceptic position over time, and particularly in 2001. This latter conclusion requires support from self-reported positions of Conservative core voters.

\section{CONSERVATIVE VOTERS' POLICY POSITIONS}

In order to verify the reports of party placement data, and to determine the placements of Conservative supporters, data are presented on the self-placements of Conservative identifiers and on perceived Conservative party placements. Table 2 presents the average policy position of Conservative party identifiers, the proportion of Conservative identifiers holding a rightwing position (defined as placements at points 8 through 10$)^{49}$ and the average perception among all respondents of the Conservative party's policy positions between 1987 and 2001 .

Table 2 confirms the descriptions given above regarding perceptions of Conservative party policy moderation on left-right issues. Respondents of the BES surveys first placed the party in 1987 at a more right of centre position, but placed the party in a more moderate centre-right position by 2001 on all issues pertaining to the left-right dimension. On European integration, respondents perceived the Conservative party to shift towards a more Eurosceptic position. These estimates all exclude 'Don't know' responses, and therefore there are grounds to conclude that voters did recognize these inverse changes on left-right and European policy.

The figures reported in Table 2 also challenge the depiction of the Conservative vote base as being right-wing on left-right issues. The data suggest that existing assumptions about core Conservative voters may simply be outdated. The average Conservative

\footnotetext{
45 Benoit and Laver, Party Policy in Modern Democracies.

46 Other dimensions included deregulation, EU peacekeeping, 'social', decentralization, Northern Ireland, Environment and a constructed dimension, 'sympathy'. The discussed issues are chosen for their relevance to the core vote debate.

47 Jane Green, 'Conservative Party Rationality: Learning the Right Lessons from the Last Election for the Next', Journal of Elections, Public Opinion and Parties, 15 (2005), 111-27; Green, 'When Voters and Parties Agree'; Thomas Quinn, 'The Conservative Party and the "Centre Ground" of British Politics', Journal of Elections, Public Opinion and Parties, 18 (2008), 179-99; Adams, Green and Milazzo, 'Has the British Public Depolarized Along with Political Elites?'.

${ }^{48}$ Benoit and Laver, Party Policy in Modern Democracies; Green, 'When Voters and Parties Agree'; Clements and Bartle, 'The European Issue and Party Choice at British General Elections'.

49 All scales in this article have been re-coded between $0-10$ where $0=$ most left and $10=$ most right.
} 
TABLE 2 Average perceived placements of the Conservative party, self-placements of Conservative party identifiers and the percentage of Conservative partisans taking positions at the most right-wing positions of each scale (8-10), BES data 1987-2001

\begin{tabular}{|c|c|c|c|c|c|c|}
\hline & & 1987 & 1992 & 1997 & 2001 & Change* \\
\hline Social Services & $\begin{array}{l}\text { Con party } \\
\text { Con partisans } \\
\% \text { right-wing }\end{array}$ & $\begin{array}{l}6.16 \\
4.24 \\
8.91 \%\end{array}$ & $\begin{array}{l}6.06 \\
3.97 \\
9.42 \%\end{array}$ & $\begin{array}{l}5.93 \\
3.40 \\
4.74 \%\end{array}$ & $\begin{array}{l}5.21 \\
3.56 \\
5.24 \%\end{array}$ & $\begin{array}{l}-0.95 \\
-0.64 \\
-3.67\end{array}$ \\
\hline Nationalization & $\begin{array}{l}\text { Con party } \\
\text { Con partisans } \\
\% \text { right-wing }\end{array}$ & $\begin{array}{c}8.14 \\
6.94 \\
49.59 \%\end{array}$ & $\begin{array}{l}7.38 \\
5.97 \\
34.02 \%\end{array}$ & $\begin{array}{l}6.99 \\
5.35 \\
25.29 \%\end{array}$ & $\begin{array}{c}6.50 \\
5.14 \\
16.99 \%\end{array}$ & $\begin{array}{r}-1.64 \\
-1.80 \\
-32.60\end{array}$ \\
\hline Inflation/unemp & $\begin{array}{l}\text { Con party } \\
\text { Con partisans } \\
\% \text { right-wing }\end{array}$ & $\begin{array}{l}5.38 \\
3.50 \\
13.30 \%\end{array}$ & $\begin{array}{l}5.44 \\
3.11 \\
11.80 \%\end{array}$ & $\begin{array}{l}5.16 \\
3.36 \\
11.01 \%\end{array}$ & $\begin{array}{l}4.88 \\
3.65 \\
10.57 \%\end{array}$ & $\begin{array}{l}-0.5 \\
+0.15 \\
-2.73\end{array}$ \\
\hline Redistribution & $\begin{array}{l}\text { Con party } \\
\text { Con partisans } \\
\% \text { right-wing }\end{array}$ & $\begin{array}{c}7.43 \\
5.65 \\
35.53 \%\end{array}$ & $\begin{array}{c}6.90 \\
5.07 \\
31.40 \%\end{array}$ & $\begin{array}{c}7.21 \\
4.94 \\
27.83 \%\end{array}$ & $\begin{array}{c}6.46 \\
5.48 \\
31.86 \%\end{array}$ & $\begin{array}{l}-0.97 \\
-0.17 \\
-3.67\end{array}$ \\
\hline European Union & $\begin{array}{l}\text { Con party } \\
\text { Con partisans } \\
\% \text { right-wing }\end{array}$ & $\begin{array}{l}- \\
- \\
-\end{array}$ & $\begin{array}{l}4.57 \\
5.36 \\
34.45 \%\end{array}$ & $\begin{array}{l}5.47 \\
6.78 \\
50.91 \%\end{array}$ & $\begin{array}{c}6.38 \\
7.32 \\
56.67 \%\end{array}$ & $\begin{array}{l}+1.81 \\
+1.96 \\
+22.2\end{array}$ \\
\hline
\end{tabular}

Note: The 1987, 1992 and 1997 values are from BES cross-sections. The values for 2001 are taken from the 2001 wave of the 1997-2001 BES panel study, due to the absence of comparable measures in the $2001 \mathrm{BES}$ cross-section. * 'Change' is the difference between the value for 1987 and that for 2001 .

Measures:

Social Services: Some people feel that government should put up taxes a lot and spend much more on health and social services (0). Other people feel that government should cut taxes a lot and spend much less on health and social services (10). And other people have views somewhere in between. Please tick whichever box comes closest to your own views about taxes and government spending.

Nationalization: Some people feel that government should nationalize many more private companies (0). Other people feel that government should sell off many more nationalized industries (10). And other people have views somewhere in between. Please tick ...

Inflation/Unemployment: Some people feel that getting people back to work should be the government's top priority (0). Other people feel that keeping prices down should be the government's top priority (10). And other people have views somewhere in between. Please tick ... Redistribution: Some people feel that government should make much greater efforts to make people's incomes more equal (0). Other people feel that government should be much less concerned about how equal people's incomes are (10). And other people have views somewhere in between. Please tick ...

European Integration: Some people feel that Britain should do all it can to unite fully with the European Union (0). Other people feel that Britain should do all it can to protect its independence from the European Union (10). And other people have views somewhere in between. Please tick...

identifier moved towards the centre or even towards the left-hand side of the policy scales over time. On inflation and unemployment, there was a modest drift towards the centre, but from a left-of-centre position. The proportions of the most right-wing identifiers (those at points 8 through 10) declined dramatically on the issue of nationalization but also on other issues. On only one issue - redistribution - is there issue alignment with the 
Conservative base, but even on this classic left-right issue, Conservative identifiers were not in the top quartile of the scale by 2001. If the Conservative party lost its most moderate supporters when it was defeated in 1997 and its most right-wing voters remained, we would expect the proportions of right-wing Conservatives to increase after 1997. This is not the case. Conservative voters were, by 2001, much more centrist on average on left-right issues than their party. In this sense, the Conservative party was perhaps playing catch-up with its voters over time, in lagged policy shifts, but towards the position of its base - and also of the majority. These data serve to undermine the argument that the Conservatives could have appealed to their most right-wing voters. They would have been appealing to a very small - and declining - proportion, if they had appealed to the existing Conservative 'right'.

The one exception to these observations is the issue of Europe. The average Conservative supporter is to the right of the Conservative party - suggesting that party policy could indeed be pulled in the direction of this base support. The positions of Conservative partisans in 1992 were already to the right of the party, suggesting that the party could have shifted over time towards its supporters, and to the prior positions of elites (see Table 1). The potential for pull towards the electoral base appears to have increased with time, so that the election of 2001 presented William Hague with a more Eurosceptic vote base than faced John Major in either 1992 or 1997. This evidence supports the core vote critique, thus far, of Conservative policy on the issue of European integration. In order to establish the degree to which the Conservative party was closer to its own voters than to potential voters, however, highlighted earlier as a necessary condition for a core vote interpretation, we also need to evaluate the spatial distance of perceived Conservative positions with those of the party's own voters, swing voters and others.

Table 3 presents data on perceived Conservative policy on entry into the eurozone in 2001, and the distance to the self-placed positions of respondents. Britain's membership of the single currency area was the European issue highlighted by William Hague in the 2001 election. The issues of taxation and public spending, and crime (defined as protecting the rights of the accused versus cutting crime) are also explored here. ${ }^{50}$ The first row of each policy scale represents the average respondent location, by party identification, and the following three rows represent the distance between the average respondent location and the average position of each party (the latter is not reported in Table 3). For example, 'Distance to Con' for Labour identifiers on taxation and public spending is 2.18 , calculated by taking the average Conservative party position (6.28) minus the average Labour identifier's position (4.10).

According to the data in Table 3, the Conservative party position on taxation and public spending was closer to Conservative identifiers than to other voters. However, the absence of a negative sign denotes that Conservative identifiers were placed, on average, to the left of their party, consistent with Table 2. The Labour and Liberal Democrat parties were both perceived to be positioned in closest proximity to Conservative identifiers, slightly left and slightly right, respectively, so that the parties with the greatest spatial advantage to the core Conservative vote were the Conservative party's opponents. These data fail to confirm the criteria established to test the interpretation that the Conservatives appealed to their core vote on this issue: the Conservative party was perceived to be to the right of public opinion on taxation and spending, but not in the direction of its vote base, and not the closest party to its vote base.

50 The 2001 BES cross-section figures for taxation are slightly but not substantially different to the figures in Table 2, which used the 2001 wave of the 1997-2001 British Election Panel Study. 
TABLE 3 Distance between the Average Perceived Conservative Party Placements and Average Self-Placement, by Party Identification and All Respondents, on the Issues of Crime, Taxation and Public Services, and Europe ('Keeping the Pound'), in 2001

\begin{tabular}{lrrrrr}
\hline \hline & Labour & Cons & Lib Dem & None & Average (all) \\
\hline Tax-spend & & & & & \\
Mean respondent position & 3.10 & 3.96 & 3.01 & 3.68 & 3.39 \\
Distance to Con & 2.18 & 1.32 & 2.27 & 1.60 & 1.89 \\
Distance to Lab & 0.92 & 0.06 & 1.01 & 0.34 & 0.63 \\
Distance to Lib & 0.82 & -0.04 & 0.91 & 0.24 & 0.53 \\
Crime & & & & & 6.29 \\
Mean respondent position & 6.03 & 6.67 & 6.14 & 6.47 & -0.36 \\
Distance to Con & -0.10 & -0.74 & -0.21 & -0.54 & -1.21 \\
Distance to Lab & -0.95 & -1.59 & -1.06 & -1.39 & -1.06 \\
Distance to Lib & -0.80 & -1.44 & -0.91 & -1.24 & 6.78 \\
f/euro & & & & & -0.19 \\
Mean respondent position & 6.38 & 8.07 & 6.24 & 6.51 & -2.86 \\
Distance to Con & 0.21 & -1.48 & 0.35 & 0.08 & -2.45 \\
Distance to Lab & -2.46 & -4.15 & -2.32 & -2.59 & -2.18 \\
Distance to Lib & -2.05 & -3.74 & -1.91 & & \\
\hline \hline
\end{tabular}

Source: BES 2001 cross-section. A negative sign denotes that the average perceived party placement is to the left of the respondent mean. The tax-spend question was included in the face-to-face post-election survey, and the crime and EU scales in the self-completion post-election survey. Average party placements:

Tax-spend: Conservatives (5.28), Labour (4.02), Liberal Democrats (3.49).

Crime: Conservatives (5.93), Labour (5.08), Liberal Democrats (5.23).

Euro: Conservatives (6.59), Labour (3.92), Liberal Democrats (4.33).

Measures:

Tax-spend: On a scale of 0 to 10 , where 0 means government should cut taxes a lot and spend much less on health and social services, and 10 means government should raise taxes a lot and spend much more, where would you place your own views?

Crime: Some people think that reducing crime is more important than protecting the rights of people accused of committing crimes. Other people think that protecting the rights of accused people is more important than reducing crime. On the $0-10$ scale below, where would you place your own views?

Keep/Replace Pound scale: Some people think that Britain should definitely replace the pound with the euro (0). Other people think that Britain should definitely keep the pound (10). On the 0-10 scale below, where would you place your own views?

On the issues of crime and economic monetary union, Conservative party positions were closer to the identifiers of the other main political parties, as well as respondents not identifying with a party, than they were to respondents identifying with the Conservatives. These findings again fail to support the core vote interpretation: the Conservative's perceived positions on these Conservative issues were in closer proximity to new and potential voters than to the existing Conservative vote base. Thus, although Conservative policy on Europe was viewed as becoming more Eurosceptic between 1992 and 2001 (Table 2), the position in 2001 on the single currency was not as Eurosceptic as Conservative voters' positions. The perceived Conservative position was closer to the positions of other survey respondents with attachments to other parties and none. Note that using the same item employed in Tables 1 and 2, relating to fully uniting or protecting independence (in the 2001 wave of the 
1997-2001 BEPS), the Conservatives remain the closest party, relative to Labour, to all respondents, including Labour identifiers, Liberal Democrat identifiers, Conservatives and those with no partisanship. ${ }^{51}$ The self-placements of BES Conservative party identifiers confirm that the Conservative base moved in a more Eurosceptic direction by 2001 (Table 2). The Conservative party Eurosceptic shift was seen in voter perceptions, CMP estimates and elite self-placements (Table 1). Table 3 confirms that this shift was one which remained in closest proximity to other voters - beyond the Conservative base. This does not deny that the policy move was one which would appeal to Conservative voters also, but a trade-off between the base and the wider electorate was not clearly in play.

If the Conservative party moved further towards its voters following the election as a lagged response to its more Eurosceptic base, we might expect to see a further Eurosceptic shift between 2001 and 2005. Unfortunately, the survey item wordings changed in the 2005 BES (where the end points became $0=$ Definitely get out of the EU, and $10=$ Definitely stay in), but the Conservatives retained a significant proximity advantage on the issue using this scale. ${ }^{52}$ Europe was downplayed in 2005 but Cameron shifted symbolically on the issue as leader. ${ }^{53}$

We do not have voter, manifesto or elite party placement data on the issue of immigration and only sporadic survey items of attitudes, but this issue was germane to accounts of the Conservatives playing to the base in the 2001 and 2005 elections. IpsosMORI data show a trend towards greater opposition to immigrants among the British public. In the 1997 survey, MORI found the net 'agree-disagree' score in responses to the statement, 'There are too many immigrants in Britain', to be +26 (most respondents agreed). ${ }^{54}$ By November 2007, this score was +46 . The 2005 British Social Attitudes (BSA) survey confirms that in 2005 all party identifiers agreed, on average, that there are 'too many immigrants let into the country'. ${ }^{55}$ Using the only party placement data we have available, the 2002-03 survey of experts, ${ }^{56}$ Conservative and Labour policies on this issue were relatively similar (13.8 and 9.0 on the 1-20 scale). According to these sources, Conservative policy was probably closest to those of the majority. If the Conservative party was further right on this issue, as on crime and European integration, it was closer to the largest majority of voters, rather than to its core vote alone.

All in all, the available survey data suggest that important changes occurred in British public opinion and party placements. Conservative voter opinion shifted in a centrist

51 The Liberal Democrat position is marginally but not significantly closer than the Conservative position to Labour partisans (0.17 difference between the Conservative and Liberal Democrat gap) and Liberal Democrat partisans (0.09).

${ }^{52}$ See Harold D. Clarke, David Sanders, Marianne C. Stewart and Paul F. Whiteley, Performance Politics and the British Voter (Cambridge: Cambridge University Press, 2009).

53 Ironically, this may be an example where Cameron was attempting to shore up his Eurosceptic voters and supporters. Cameron withdrew Conservative MEPs from the European People's Party (the centreright grouping in Europe) and negotiated a new grouping of Eurosceptic parties.

54 Source: http://www.ipsos-mori.com/content/attitudes-towards-immigration.ashx. The net 'agree minus disagree' score was the percentage of 'strongly agree' and 'tend to agree' responses minus the percentage of 'tend to disagree' and 'strongly disagree' responses.

${ }^{55}$ Using the 2005 British Social Attitudes (BSA) survey, and the question, 'Do you think there are too many immigrants have been let into the country or not?', 89.5 per cent of Conservative identifiers agreed, compared with 78.3 per cent of Labour identifiers, 66.4 per cent of Liberal Democrat identifiers, 73.7 per cent of people identifying with 'other' parties, and 86.5 per cent identifying with no party (total $N=2,093)$.

56 Benoit and Laver, Party Policy in Modern Democracies. 
direction on left-right issues, subsequent to the end of the Thatcher era of British politics, so that the closest parties to Conservative partisans on left-right issues were the party's main opponents. ${ }^{57}$ At the same time, Conservative voter opinion shifted to the right on Europe. However, this Eurosceptic preference was shared by supporters of the other major parties, alongside attitudes to crime and immigration. There is an important distinction to be made, therefore, about the electoral opportunities for the British Conservatives in opposition between left-right issues and EU and libertarian-authoritarian issues. Quinn remarked that the Conservatives could not move to be the closest party to the median voter on left-right issues in 2001 and 2005, because to do so would have meant leapfrogging Labour. ${ }^{58}$ Therefore, the issues beyond the classic left-right dimension of competition - crime, Europe and immigration - provided the Conservatives with a unique spatial advantage, but not singularly or in closest proximity to the party's own core vote. In these respects, spatial policy comparisons fail to give clear support to the core vote account, but highlight, instead, the vote-maximizing logic of focusing on issues on which the Conservatives had a spatial proximity advantage.

\section{CONSERVATIVE VOTERS' POLICY PRIORITIES: ISSUE SALIENCE BETWEEN 1998} AND 2007

If we assume that core Conservative issues are those on which the Conservative party was described as focusing upon in its 2001 and 2005 campaigns, the expectation must be that Conservative voters placed greater priority on issues of crime, Europe, taxation and immigration. ${ }^{59}$ Likewise, if we consider the issues we would not expect Conservative voters to prioritize, then issues such as healthcare and the NHS, education and unemployment may be defined as classic Labour issues.

The six-part Figure 1 plots the percentage of respondents rating each issue as 'the most important issue facing the country today' among Conservative respondents by vote intention, Labour respondents, Liberal Democrats, respondents undecided how to vote and respondents reporting an intention not to vote. The issues analysed are health (A), crime (B), education (C), Europe (D), unemployment (F) and asylum/immigration/race relations $(\mathrm{G}) .{ }^{60}$ The observations for taxation were very low throughout the whole period, never reaching above 2 per cent, and so comparisons are not presented. Respondents with Conservative vote intentions are shown in bold.

The issues graphed in Figure 1 reveal a strong pattern of similarity between Conservatives and other voters in issue salience and also in its variation over time. When each issue is higher in salience for one group, it tends to be higher for others. These data challenge a very simple assumption that different parties' voters hold distinctive, stable and consistent issue commitments. There is considerable fluctuation across each

57 Post-2005 data indicate that public opinion may have subsequently moved in a low taxation direction, so that perceived Conservative policies in 2001 and 2005 would be closer. See John Curtice, 'Back in Contention? The Conservatives' Electoral Prospects', Political Quarterly, 80 (2009), $172-83$.

58 Quinn, 'The Conservative Party and the "Centre Ground" of British Politics'.

59 Butler and Kavanagh, The British General Election of 2001; Philip Cowley and Stuart Quayle, 'The Conservatives: Running on the Spot', in Andrew Geddes and Jonathan Tonge, eds, Labour's Second Landslide: The British General Election 2001 (Manchester: Manchester University Press, 2002), pp. 47-65; John Bartle, 'Why Labour Won - Again', in Anthony King, ed., Britain at the Polls, 2001 (London: Chatham House, 2002); Seldon and Snowdon, 'The Conservative Campaign'.

${ }^{60}$ MORI includes all race/immigration and asylum terms in one category. 
(a)

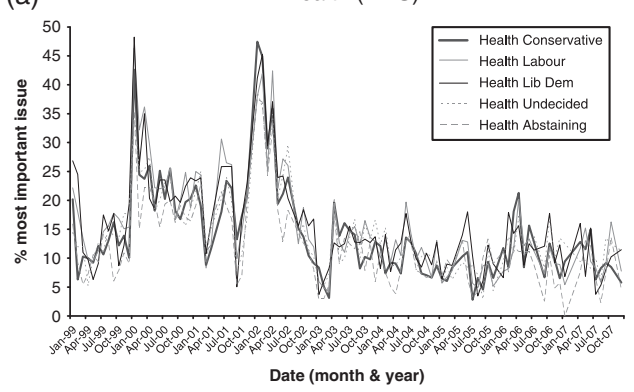

(c)

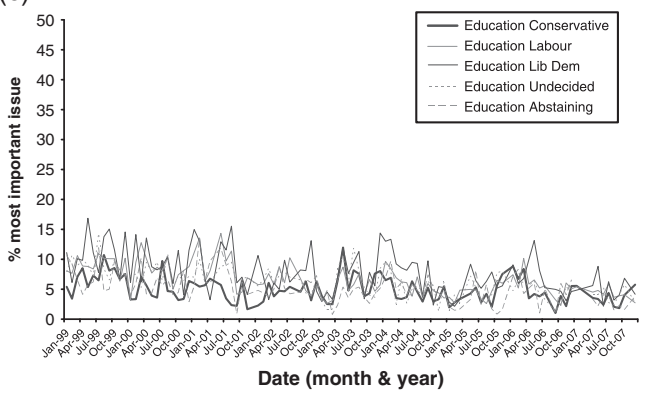

(e)

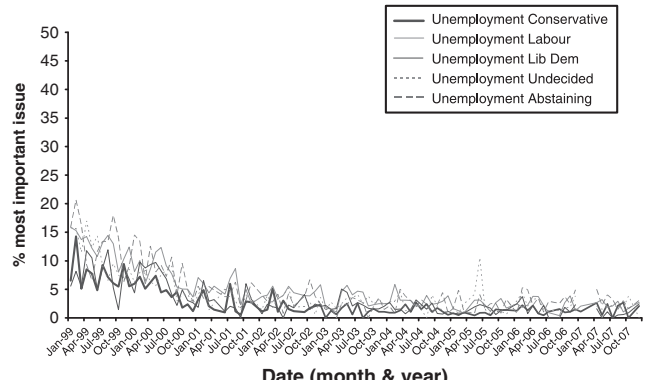

(b) Crime

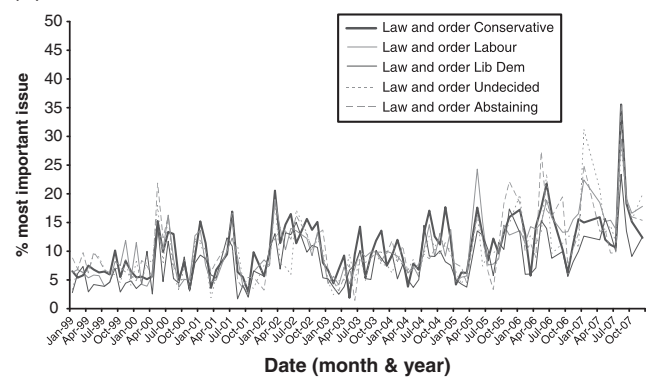

(d)

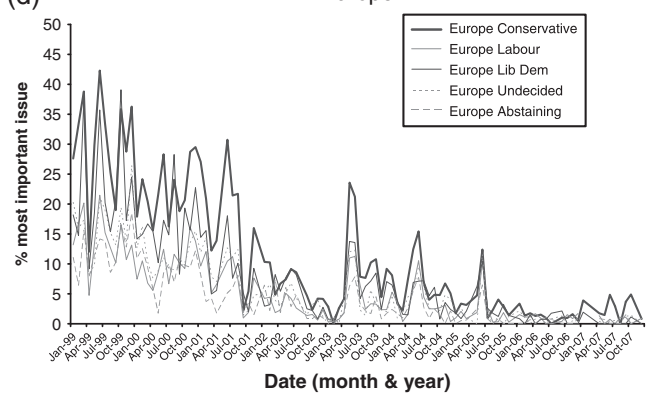

(f)

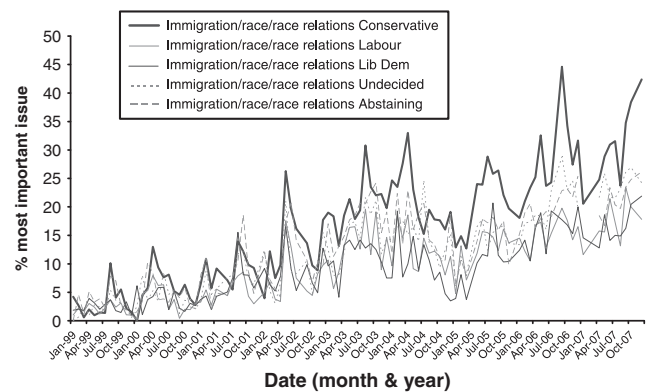

Fig. 1. The proportions in percentages of Conservatives, Labour supporters, Liberal Democrat supporters, respondents not intending to vote and undecided respondents (by vote intention) rating issues $(a)-(f)$ (health, crime, education, unemployment, the economy, immigration) the most important issue, January 1999-December 2007

Data: Ipsos-Mori.

issue, and when an issue rises in prominence for one set of respondents, it does so among others. The stability in Conservative vote intentions throughout this period (see Figure A1 in the Appendix) suggests that there is genuine variation in the issues rated most important in these monthly cross-sectional data. ${ }^{61}$

On two issues, Europe and asylum/immigration, there is some support for the criteria concerning divergent issue agendas, but the evidence is mixed and the causal relationship

${ }^{61}$ It would be possible to analyse change among the same respondents using panel data. However, since these panel study questions occur in elections, we would not be able to distinguish changes in issue salience from responsiveness to party agendas in campaigns. 
requires consideration. On both issues, when the issue rises in importance for all respondents, it does so more steeply for Conservatives. In the first half of the time series, Conservatives were slightly more likely to rate Europe the most important issue between January 1999 and the early part of 2002, with a peak coinciding with the 2003 local elections. It is striking, however, that between July 2003 and December 2007 no more than 15 per cent of Conservatives chose this issue as the most important, even during the 2004 European elections, and the numbers are minimal from July 2005 onwards. Conservatives were as unlikely as other respondents to rate asylum/immigration as most important between 1999 and 2001 - including during the 2001 campaign, which was described as an appeal to the base - but were then disproportionately more likely to cite this issue as it rose in salience. Two interpretations can be offered. The first is that these issues are 'hot button issues' for Conservatives: when they enter the agenda, Conservatives are particularly concerned about them. This would support, in part, the core vote account, since the Conservative party may have focused on issues it thought would disproportionately energize its voters. However, to have focused on Europe or immigration in both periods would not have conflicted with appealing to other voters for whom the issues also rose in prominence: a key test for core vote assumptions, and a focus in 2001 on immigration could not be considered an appeal to the base. The second is that the causal arrow of issue-agenda priming works from the party to the voters, as argued by Iyengar and Kinder, ${ }^{62}$ and may work particularly strongly from the party to those voters receptive to party messages, as argued by Zaller. ${ }^{63}$ This would mean that the Conservative party should try to avoid issues such as Europe and immigration, since its voters only care disproportionately about those issues when the party puts them centre stage (or other parties do so). However, we might question the degree to which David Cameron has focused on immigration, which is nonetheless most salient among Conservatives under his leadership. It is also possible that such issues could become a rod for the Conservative party's back if minor parties, such as the United Kingdom Independence Party (UKIP) or the British National Party (BNP), successfully increased the salience of those issues. The agenda-shaping ability of these parties could be limited, however. In the 2004 European elections, in which UKIP came second in votes, the rise in the salience of Europe was small and short-lived (Figure 1D). It seems plausible that voters are reacting, at least in part, to their party's issue agenda, and to the broader change in salience within the country as a whole. Both interpretations challenge the simple assumption that a focus on immigration would appeal only to Conservative voters; the rise in immigration salience occurs among each respondent group.

It is particularly interesting that ratings of taxation were very low for all respondents. Given that taxation was thought to be a core Conservative vote issue in 2001 and 2005, the lack of emphasis by Conservatives and all respondents suggests that the party had another reason for focusing on this issue in its campaigns, such as a rating for competence or issue ownership.

On four issues - health, crime, education and unemployment - there is clear 'partisan issue salience convergence'. It is striking that on the issue of healthcare (NHS) - a classic Labour issue - Conservative voters are equally or more likely to rate this issue 'the most important facing the country'. These data do not, therefore, support the argument that the Conservatives failed to focus on the issue of healthcare because it was an issue its core

\footnotetext{
${ }^{6}$ Shanto Iyengar and Donald R. Kinder, News that Matters: Television and American Opinion, American Politics and Political Economy (Chicago: University of Chicago Press, 1987).

63 Zaller, 'Information, Values, and Opinion'; Zaller, The Nature and Origins of Mass Opinion.
} 
TA B LE 4 Correlations between Conservative Respondents and Others by Vote Intention in Rating Crime, Europe, Immigration, Health, Education and Unemployment as the Most Important Issue Facing the Country, between January 1999 and December 2007, and the Average Gap in Salience Ratings by Vote Intention

\begin{tabular}{|c|c|c|c|c|c|c|}
\hline & Crime & Europe & Immigration & Health & Education & Unempl't \\
\hline \multicolumn{7}{|l|}{ Cons - Labour } \\
\hline Correlation & 0.81 & 0.96 & 0.91 & 0.91 & 0.46 & 0.85 \\
\hline $\begin{array}{l}\text { Average salience gap } \\
\text { Cons - Lib Dem }\end{array}$ & 0.19 & 6.23 & 6.85 & -1.42 & -1.62 & -2.33 \\
\hline Correlation & 0.79 & 0.92 & 0.85 & 0.87 & 0.40 & 0.80 \\
\hline $\begin{array}{l}\text { Average salience gap } \\
\text { Cons - undecided }\end{array}$ & 2.39 & 3.57 & 7.40 & -1.45 & -2.96 & -0.44 \\
\hline Correlation & 0.72 & 0.94 & 0.90 & 0.90 & 0.48 & 0.76 \\
\hline $\begin{array}{l}\text { Average salience gap } \\
\text { Cons - will not vote }\end{array}$ & 0.67 & 5.45 & 4.78 & -0.21 & -1.20 & -1.43 \\
\hline Correlation & 0.76 & 0.89 & 0.89 & 0.89 & 0.36 & 0.78 \\
\hline Average salience gap & 0.09 & 7.23 & 4.12 & 2.08 & -0.20 & -2.19 \\
\hline
\end{tabular}

vote considered unimportant. Conversely, it is striking that on crime - a classic Conservative issue and one defined as a core vote issue - Conservative voters are no more likely to rate the issue highly, again throwing doubt on the core vote argument. The issue of education is consistently low in salience among all respondents and where it rises in salience, it appears to do so among Liberal Democrat voters. Also, and interestingly, unemployment - perhaps the clearest Labour issue in British politics - reveals similar variation in salience (although low) for Conservatives and other survey respondents alike.

These computations demonstrate considerable issue salience convergence and a pattern of similar responsiveness to variation in issue salience. To the degree that issues such as Europe and immigration may be hot button issues, the trade-offs between Conservative voters and other voters are not nearly as great as one may think. These interpretations can be seen most clearly in Table 4, which reports the correlations in issue salience between each group for each issue and the 'average salience gap' - the average difference between Conservatives and others in the percentage rating each issue as most important over the period.

Table 4 shows that the correlations between groups of voters rating Europe and immigration salient are as high or higher than those for health, crime and unemployment. When Europe or immigration is high (low) on the agenda, the issue is high (low) among all potential voters and these correlations are very high. The correlations are high across all issues, except education, which was an issue for which the average salience was low.

Overall, the criteria established to test the idea of a core vote issue receive weak support, except where there is some greater priority placed on Europe and immigration. However, the data also suggest that parties can either move on to new issues because a party's own supporters follow the issue emphasis of their party or fail to rate these issues important consistently over time, or they can campaign on their existing issues because voters beyond the base are responsive to the same issue agenda. It is also possible that parties have little control on the issues salient to their voters. In this case, the Conservative party should be aware of the potential for disproportionate concern for the issues of immigration and Europe, but the trade-off between an appeal to the base and an 
appeal to the broader electorate does not appear to be significant. The apparent similarity between the Conservative base and the concerns and positions of other voters all serve to question party-base assumptions. New questions emerge for a strategy so widely derided as failing to maximize the Conservative vote.

\section{AN ALternative EXPLANATION: 'CONSERVATIVE ISSUES' VERSUS 'CORE VOTE ISSUES'}

If we are to conclude that unpopular parties focus campaigns on issues of relatively low salience, we still need to explain the selection of these apparently unsuccessful strategies. ${ }^{64}$ One response is to assume that parties are deterred from vote-seeking strategies due to internal interests and priorities: a policy-seeking or activist-driven appeal in conflict with an electoral vote-seeking explanation. Another is to seek evidence in support of votemaximizing incentives. This article works on the assumption that unpopular parties should be particularly motivated by winning more votes. By increasing popular support by a variety of means, parties energize their activists, donors and partisans, as well as their core and potential voters.

Webb argued that Conservative issue priorities in 2001 were driven by the rational strategy of selective emphasis on issues on which the Conservatives were closest to public opinion and most trusted. ${ }^{65}$ According to the saliency theory of Budge and Farlie, ${ }^{66}$ the issue ownership theory of Petrocik ${ }^{67}$ and also Riker's dominance/dispersion principle, ${ }^{68}$ parties can be expected to emphasize their best issues but downplay the significance of opponents' strengths. This explanation has been supported by analysis of party strategies and vote choices in the 2005 general election. According to Green and Hobolt, the Conservative campaign in 2005, focusing on crime, education, health, taxation and immigration (in descending order of emphasis, measured by content analysis of press releases, leader speeches and party election broadcasts), could be explained by more positive Conservative issue ratings. ${ }^{69}$ These studies suggest that Conservative issue strategies may have been driven by vote-seeking goals relating to vote winning via issue saliency or issue ownership. An extension of this explanation can be offered: unpopular parties are constrained by the number and salience of issues on which they are rated positively, since parties are rejected from office - alongside losing public trust - on the most important issues of the day. Therefore, when a party loses popularity, its best issues are likely to be low in salience and the number of these available issues will be limited. This explanation may be

\footnotetext{
${ }^{64}$ Note that it is not possible to test the question of whether the campaigns failed to win potential votes, but the conclusion rests on the shared wisdom that they failed to improve the party image, at the least.

${ }^{65}$ Paul Webb, 'Parties and Party Systems: More Continuity than Change', Parliamentary Affairs, 55 (2002), 363-76.

${ }^{66}$ Ian Budge and Dennis Farlie, Voting and Party Competition: A Theoretical Critique and Synthesis Applied to Surveys from Ten Democracies (London: Wiley, 1977); Ian Budge and Dennis Farlie, Explaining and Predicting Elections: Issue Effects and Party Strategies in Twenty-Three Democracies (London: Allen \& Unwin, 1983).

${ }^{67}$ John Petrocik, 'Issue Ownership in Presidential Elections', 1996; Petrocik, Benoit and Hansen, 'Issue Ownership and Presidential Campaigning'.

${ }^{68}$ William H. Riker, The Art of Political Manipulation (New Haven, Conn.: Yale University Press, 1986); William H. Riker, 'Rhetorical Interaction in the Ratification Campaigns', in W. H. Riker, ed., Agenda Formation (Ann Arbor: University of Michigan Press, 1993), pp. 8-123.

${ }_{69}$ Jane Green and Sara B. Hobolt, 'Owning the Issue Agenda: Party Strategies and Vote Choices in British Elections', Electoral Studies, 27 (2008), 460-76.
} 
particularly helpful in accounting for the campaign strategies of the Conservatives in 2001 and 2005.

In order to explore this explanation, interviews were undertaken with the party leaders covering the period between 1997 and 2005; the Rt. Hon. William Hague MP, the Rt. Hon. Iain Duncan Smith MP, and the Rt. Hon. Michael Howard QC MP. Party leaders represent the apex of political party decision making and each was responsible for agreeing and leading the campaign and strategy. Each leader was asked to define their strategy, report the aims and objectives, expectations and considerations, and to identify their target vote. ${ }^{70}$

It should be noted that elite interviews may produce biased accounts, but the data provide both a defence and also self-reported negative assessments. Furthermore, the claims are put under the spotlight of additional quantitative evidence concerning the number and type of Conservative issue ratings. These ratings are taken from yearly Ipsos-Mori data between 1992 and 2008, using the survey item,

I am going to read out a list of problems facing Britain today. I would like you to tell me whether you think the Conservative party, the Labour party or the Liberal Democrats has the best policies on each problem.

The measure provides the only available survey item across a range of sufficient time points. The difference between the percentage citing the Conservatives as the best party, minus the percentage citing Labour as the best party, is plotted as the 'net Conservative issue advantage', against the net Labour minus Conservative vote intention (in percentages), to reveal the set of issues on which the Conservatives could hope to campaign if they subscribed to the saliency or issue ownership theory of winning votes in elections, alongside changes in electoral support.

INTERVIEW EVIDENCE AND 'PARTY WITH THE BEST POLICIES' DATA

The interviews are reported in the chronological order of leaders: William Hague (WH), Iain Duncan Smith (IDS) and Michael Howard (MH).

William Hague outlined his issue agenda in the 2001 British general election:

It was meant to be crime, Europe, tax, and then education as a kind of loss leader. There was no way of winning an election on health and education ... But to show that we weren't just on about Europe, crime and tax. And [there was] one day, one in the whole campaign on asylum ... You have to find the issues that you have a relative advantage. On tax, crime and Europe, and asylum, we had a relative advantage.

Hague referred to a relative advantage on Europe, taxation and crime. Table 1 showed that the Conservatives were positioned closer to voters on Europe and crime. On taxation, the perceived distances were greater. However, it was Hague's contention that the party had a relative advantage on that issue, as well as on asylum. He also declared that, in 2001, there was 'no way of winning an election' on health and education. On these issues, Labour had a commanding advantage. Hague further argued that Europe was an issue

\footnotetext{
${ }^{70}$ Interviews were semi-structured so that the same questions were posed. Each was conducted within one year of the individual being leader, so that any post hoc rationalization could be minimized. The interviews were also cross-validated by twenty interviews with other senior Conservatives. All interviews were recorded and transcribed in full.
} 
that could win new votes for the Conservatives because those beyond the Conservative vote agreed with the party (supported in Table 3). It was also an issue on which the Conservative party could energize its base. He said:

The evidence was, from surveys, focus groups etc. that most voters agreed with the Conservative position on Europe but didn't realize it was a Conservative position. So it ought therefore in theory to be an issue on which you can win people over. Clearly it was also an issue which energized Conservative voters, and we had seen that in the European elections.

The Conservatives were criticized in 2001 for focusing on this issue given its low salience. Figure 1 (D) showed that the issue was rated important among other voters beyond just those intending to vote Conservative. There is support for Hague's view that the issue was one on which other voters agreed with the Conservatives (see Table 3), and which had some potential (in terms of perceived importance) to mobilize votes. ${ }^{71}$ Hague's focus and style were viewed as out of touch and Labour successfully neutralized the Conservative position. ${ }^{72}$ Nevertheless, to have hoped to energize Conservative support and to focus on a relative issue advantage does not equate to the issue being chosen only as an appeal to the core vote.

William Hague also defended his decision to include the issue of immigration: 'People who think that that's a faulty strategy should look at what's happened in most countries over the last two years in elections, where it has been an absolutely fundamental issue in moving votes in general elections.'

The Conservatives chose to focus on the issue for one day (according to Hague). Hague's explanation was that one day was sufficient to get the point across. It was undoubtedly also the case that the issue was controversial and therefore dangerous for an unpopular party to focus upon. In 2001, however, the issues were reportedly chosen as ones on which the party was positioned optimally, and on which the party was most trusted by swing voters, giving the party a plausible advantage. Hague continued: 'But among the suburban voters the only issues on which we had an advantage over Labour were tax and crime and Europe, and asylum. So if they were middle England, those were still the best issues to go for them on.' Hague's stated rationale is consistent with the saliency theory and potentially (but not explicitly) the issue ownership theory of Petrocik. ${ }^{73}$ Hague emphasized, 'I think there is no doubt that any party that fights an election on issues where the opponents are far in the lead is asking for it.' The issues which were most salient were most positively rated for Labour, and the gulf between the party ratings on the most important issues was considerable. According to Hague, focusing on healthcare would have put one of Labour's issues centre stage and the Conservatives had a relatively small number of positive issues which were lower on the public's agenda:

If Labour had a fifteen point lead in a poll, tax would be plus two for the Conservatives. Crime would be level, Europe would be plus four for the Conservatives and asylum would be plus ten. And then transport, education and health would all be minus thirty. And so it's absolutely stark when you look at polling evidence on what the Conservatives should fight that particular election on. It would have been amazing to have done anything else.

\footnotetext{
${ }^{71}$ Analysis of the vote also supports this contention. See Geoffrey Evans, 'European Integration, Party Politics and Voting in the 2001 Election', British Elections and Parties Review, 12 (2002), 95-110.

${ }_{72}$ Bartle, 'Why Labour Won - Again'.

${ }^{73}$ Petrocik, 'Issue Ownership in Presidential Elections'; Petrocik, Benoit and Hansen, 'Issue Ownership and Presidential Campaigning'.
} 


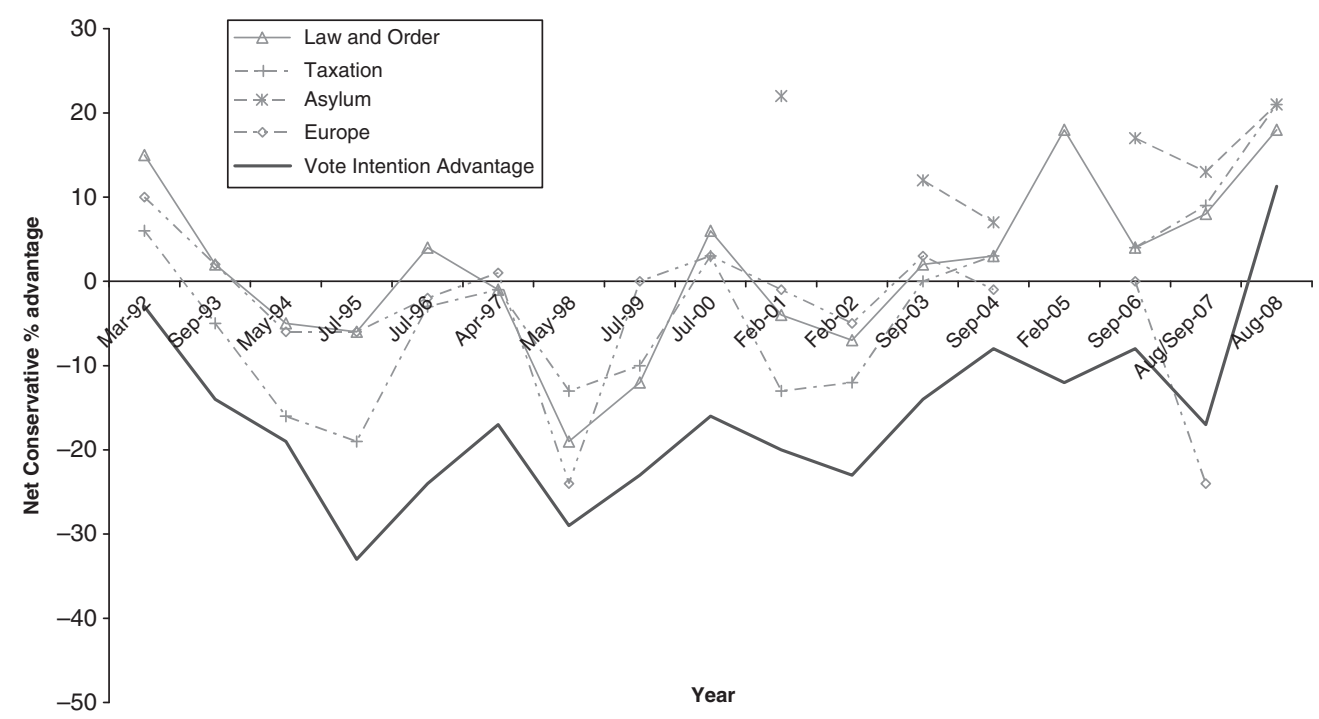

Fig. 2. Net Conservative Advantage (Conservative percentage minus Labour percentage) across 'Conservative' Issues, and Vote Intention, between 1992 and 2008)

Source: Ipsos-MORI, 'Which party has the best policy' data.

To evaluate this claim, Figure 2 presents the net Conservative rating on four issues, crime, Europe, taxation and immigration ${ }^{74}$, as well as net Conservative vote intention (percentage Conservative minus percentage Labour vote intention), between 1992 and 2008, including the 1997 to 2001 period. Figure 2 shows that Conservative ratings on these issues were more favourable to the Conservatives than their overall electoral support. Interestingly, only on immigration did the party have a very clear lead, although we can only evaluate this from 2001. The Conservative's 'best issues' were barely positive for the party between 1994 and 2003, so that Labour even had a lead on traditional Conservative issues, although these issues offered potential and relative advantages. According to these data, William Hague faced a very narrow potential issue agenda, unless, as he argued, the party moved on to Labour's clearest and most formidable policy strengths.

Figure 3 shows the net Conservative ratings on health, education, the economy and unemployment - those issues which should have been strongest for Labour. Although the issue of unemployment was not politically salient in the time period in question, it is an issue which we would expect left-wing parties to 'own' and the economy was a prominent issue in Labour's 2005 campaign when Labour also had a commanding lead on the issue. ${ }^{75}$

The data in Figure 3 support Hague's observation concerning the leads held by Labour on health and education. Between 1992 and 2001, if Labour was supported overall in vote intention (and the Conservatives supported less), Labour's advantage on health, education and unemployment saw a commensurate increase that was greater than vote intention support. In the earlier period, Labour's leads on these issues were commanding. It is also interesting to

\footnotetext{
74 The question was asked only in relation to immigration, asylum and race relations (a combined category) in 2001, 2003, 2004 and from 2006.

${ }^{75}$ Green and Hobolt, 'Owning the Issue Agenda'; Clarke, Sanders, Stewart and Whiteley, 'Performance Politics and the British Voter'.
} 


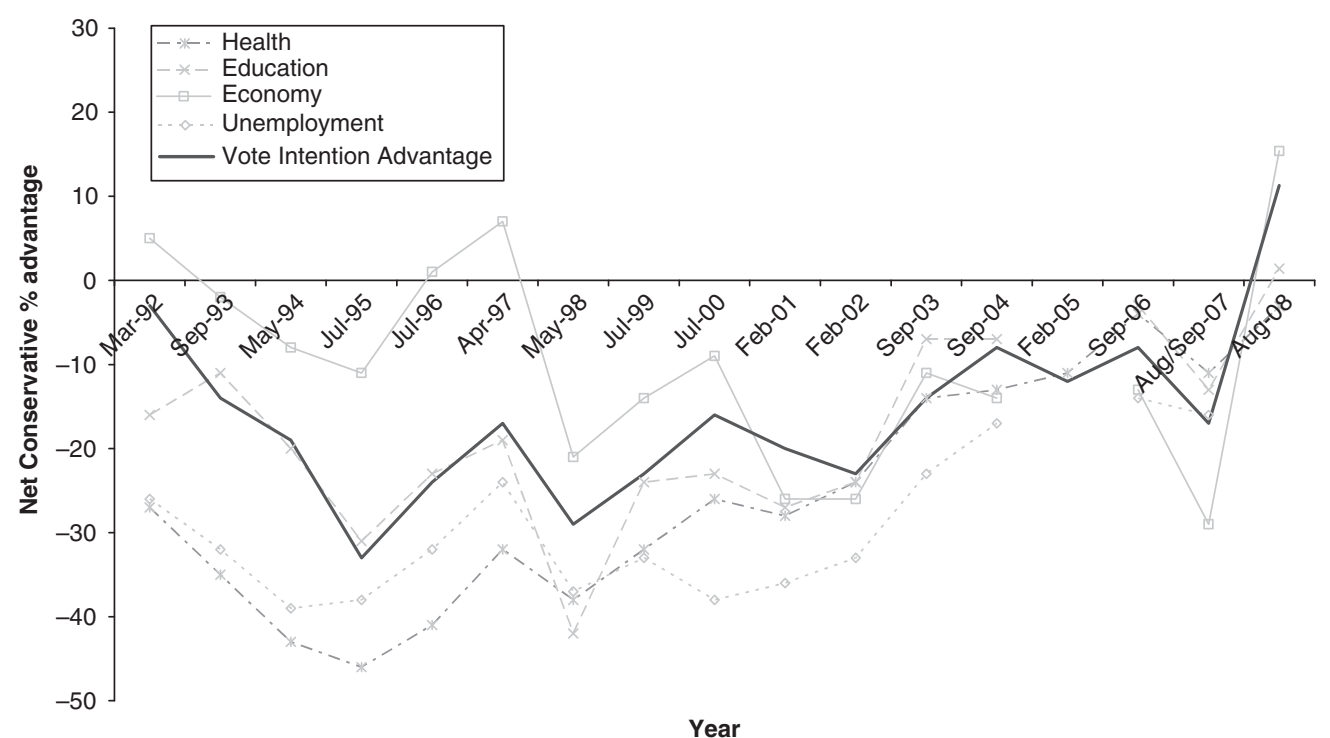

Fig. 3. Net Conservative Advantage (Conservative percentage minus Labour percentage) across 'Labour' Issues and Vote Intention between 1992 and 2008

Source: Ipsos-MORI, 'Which party has the best policy' data.

note how the rating on unemployment tracks with the other issues, and yet Labour's focus on this issue cannot be thought, by any observer, to have been significant. This lends support to an interpretation that Labour was simply rated more positively on issues associated with the party, and this increases and decreases as overall popularity fluctuates.

Asked why the Conservative party could not address Labour's strengths earlier on in the parliament, Hague pointed to Labour's commanding lead overall, a lack of anger with the government needed for opposition parties to make an inroad, and the time constraints given immediate requirements in 1997 simply to 'keep the party alive nationally'. Where there had been a palpable sense of anger with the government in seats most badly affected by the foot and mouth disease, ${ }^{76}$ the Conservatives saw some of their largest swings. Strategies to move on to new issues and a sustained initiative on education over the course of the parliament had seen no improvement in poll ratings or received any attention or 'cut through'. Hague said: 'The first half of the parliament particularly, to some extent throughout the parliament, we found it very difficult getting into the news at all, and the criticism often made of us was invisibility even though we felt we were doing a lot.' The last constraint was a need to resolve internal party differences on Europe:

Therefore a major thing we had to do, which of course prevented us getting on to all these other subjects to change the attitudes for a long time was to arrive at a policy which would satisfy most of the party without the minority leaving it ... that took, you know, some Shadow Cabinet resignations, the ballot, but really eighteen months to sort that out... Doing nothing would have created a bigger battle. ${ }^{77}$

\footnotetext{
${ }^{76}$ A cattle disease, which forced farmers to destroy livestock and the government to restrict rural transport, led to the postponement of the 2001 general election by one month.

77 The ballot was a member survey inviting support for Hague's policy of ruling out membership of the eurozone for two parliaments.
} 
In this regard, European policy and internal party difficulties delayed a process of recovery. This typical Conservative issue was undoubtedly of importance to the Conservative party, and it was problematic, but it was also an issue on which the Conservative party could hope to win votes.

There was a shift in the extent of Labour's lead on many issues. Between 2002 and 2004, the gap narrowed between Conservative and Labour vote intentions and between evaluations of both parties on all issues (Figures 2 and 3). According to William Hague, the narrowing gap could have made it possible for subsequent Conservative leaders to campaign on more issues, as well as benefiting from more clear advantages on taxation, Europe, crime and immigration:

I see no contradiction in pursuing the strategy of the last election and supporting today's strategy of the party. It follows from what I said that the party will be in a stronger position in the next election if it can shift those fundamental perceptions and can then fight on a broader front, including on some of the public service issues.

Iain Duncan Smith's strategy was not tested in an election campaign. He was Conservative leader for two years and was replaced before the 2005 general election. According to his account, his strategy differed from Hague's and Michael Howard's in his efforts to change the party's focus onto 'Labour issues' - even to positions which might be defined as to the left of New Labour - in an effort to redress problems with the Conservative image. Duncan Smith described his efforts as being about 'breaking free from 1997': 'That's really how people remember Thatcherism: as this hard-hearted creed where people basically got told off all the time ... So breaking out of that script - that's what I mean by breaking free from 1997.' Duncan Smith described previous Conservative voters as leaving the party because it seemed to govern for a narrow segment of society, rather than all, and these were the voters the party now needed to win back. They were not defined by commitments on certain issues or positions: 'That group left us because they thought a number of things about us: that we were incompetent, that we had hurt them and others, that we were not a party that, as far as they were concerned, really seemed to be fit for government.' Existing evidence gives some support for this view. Evans argued that it was the image that the Conservatives were 'good for one class' rather than 'good for all' that led to significant losses leading up to the 1997 election. ${ }^{78}$

Duncan Smith's aim was to focus the party's attention upon the least well off, to gain attention by doing something people did not naturally associate with the Conservative party, such as poverty initiatives and tours of Britain's most deprived inner cities:

We needed the sense of us to be, not, 'these people are selfish people that hate each other and row about all the people they hate', but to be 'well actually these people are ok'. That's all. OK... That gives us the license to be on other wider political issues as well. You need to earn the right, basically.

This strategy was designed to change the issue agenda in order to change the image of the party. However, it could also be interpreted as a positional strategy. Focusing on issues traditionally associated with the left would enable the Conservative party to be pulled in the minds of voters towards a notional centre defined as being in touch and reasonable. Hindmoor's concept of a 'political centre' rather than a spatial 'electoral centre' appears consistent with Duncan Smith's analysis. ${ }^{79}$

\footnotetext{
78 Geoffrey Evans, 'Economics and Politics Revisited: Exploring the Decline in Conservative Support, 1992-1995', Political Studies, 47 (1999), 139-51.

${ }^{79}$ Andrew Hindmoor, New Labour at the Centre: Constructing Political Space (Oxford: Oxford University Press, 2004).
} 
Duncan Smith described relevant constraints referring to intra-party discontent about moving away from a focus upon traditional Conservative issues. Although the scale of these objections may have been small, he pointed to concerns raised, quoting other MPs:

So if they don't see the polls change at the next monthly trackers, or whatever, then they start talking amongst themselves ... what happens is that starts to grow and grow and grow and then people will have to come and see you. 'We've got to go on to tax. This stuff doesn't mean anything. Why aren't we saying anything on Europe?'

Such descriptions highlight right-wing sentiment in the party arguing for a focus on traditional issues. Under a leader with a stronger mandate it is possible that the same objections would not have been made. Nevertheless, parliamentary pressure was exerted upon Iain Duncan Smith. Duncan Smith described a demand for weekly or daily success:

It comes down to a very short term mentality here in the House ... we live a weekly process ... The problem is that they want success immediately. They think that when you announce something or you make a speech it should have immediate cut through or it's a waste of time.

That the Conservatives' success may not have been attributable to its weekly issue strategy, but to the general context in which any party fights, may be an insight which moved David Cameron away from traditional Conservative issues. However, Iain Duncan Smith believed that his strategy was not predicated on the issue saliency or ownership theories, in contrast to the account given by William Hague. Michael Howard's strategy was, however, reportedly more similar to Hague's.

Michael Howard did not set out to change or challenge the perception of the Conservative party in ways similar to those described by Duncan Smith, but he differed from the 2001 strategy consciously by focusing upon issues of high salience, including health and education. It was also notable that Howard delivered a much more disciplined and organized campaign. ${ }^{80}$ Michael Howard explained his approach:

The best way of getting people to focus attention on the Conservative party and being persuaded to vote for the Conservative party was to identify those issues which people care most about in their ordinary daily lives and to try and relate those concerns and anxieties which people had, to specific policies which the Conservative party could produce ... school discipline, clean hospitals, lower taxes, more police and controlled immigration. And that was the strategy.

By 2005, in contrast to 2001, two 'Conservative issues', crime and immigration, had become higher in salience (see Figure 1). Talking about Conservative issue strengths did not present a trade-off between low salience and competence or proximity. The logic is, therefore, similar to that employed by Hague. The focus in 2005 was on issues of Conservative strength, which were also more salient (as was Europe in 2001), but including public service issues where Labour's advantage was now weaker. Michael Howard was critical of the campaign fought on Europe in 2001, however, differentiating his own campaign in this respect:

One obvious difference between the 2005 campaign and the 2001 campaign is that we spoke about Europe an awful lot in the 2001 campaign, and about the euro and so on and so forth ... that was an example of my giving an important subject less emphasis than I might

${ }^{80}$ Philip Cowley and Jane Green, 'New Leaders, Same Problems: The Conservatives', in Andrew Geddes and Jonathan Tonge, eds, Britain Decides: The British General Election of 2005 (Basingstoke, Hants.: Palgrave Macmillan, 2005). 
have done, because it was an election campaign and I wanted to focus on the things I thought would really matter to people and change the way they voted.

As shown in Figure 1, Europe was far more important in 2001 than in 2005, and so omitting the issue from the 2005 campaign could also be seen as a decision to focus on issues on which the Conservatives had a relative advantage, and which were salient (such as immigration). Also, by 2005, Figure 3 showed that Labour's commanding lead on issues such as health and education had declined. Michael Howard was not, therefore, presented with the same trade-offs between competence and trust and issue salience as those confronting Hague. Michael Howard stated that he disagreed that a political party should avoid issues on which an opponent is perceived as strongly competent.

MH: $\quad$ If I had my time again I'd talk about exactly the same things.

INTERVIEWER: But health is such a Labour issue.

MH: I don't think you surrender the ground.

Despite this argument, however, Howard also conceded that his strategy did relinquish the issue of the economy because of Labour's commanding lead in perceived competence: 'We didn't talk about the economy very much ... the judgement was, whatever might be the truth, most people think Gordon Brown's doing a reasonable job in managing the economy, so if you talk about that you will sort of be spitting against the wind.' Howard, therefore, took the same decision on the economy in 2005 as Hague did on health in 2001. By avoiding an opponent's strengths for fear of making those issues central to the election, both strategies were consistent with the saliency theory of Budge and Farlie: parties should focus on their own strengths, and avoid those of their opponent. ${ }^{81}$ Howard also described how he avoided the issue of Iraq, for positional reasons (the public were strongly opposed to the war, but the Conservatives had supported it), but named it as his only regret, believing that a mid-way position, if credible, could have garnered support. ${ }^{82}$

At the time of their campaigns, both Howard and Hague did not consider it detrimental to talk about traditional Conservative issues, even if those issues held the potential to make the Conservative party appear more right-wing or traditionally conservative. On the issue of immigration, Howard said:

Of course, it's perfectly true that in talking about immigration you run the risk, and we did run the risk, of being accused of pandering to the right and all that sort of thing. And that's the spin that Labour put on it, I suppose, with the benefit of hindsight, quite effectively, but actually it undoubtedly was and is a real problem that people far beyond the confines of core Tory voters cared quite passionately about.

\footnotetext{
${ }^{81}$ Budge and Farlie, Voting and Party Competition; Budge and Farlie, Explaining and Predicting Elections.

${ }^{82}$ Howard said: 'The thing I regret most is that I don't think I ever properly and convincingly explained where I stood on the war ... I never really explained that - yes I'm in favour of the war, yes I still think it was right to get rid of Sadam Hussein, but we at the time said that you needed to plan for what came after the war, and if [there had] been proper planning and if the Iraqi army and the Iraqi police hadn't been disbanded, and there hadn't been this terrible vacuum everything could and almost certainly would have been different. And that was my view. That was my position ... People said to me "lay off Iraq because whenever you say anything about Iraq it sort of goes pear shaped" which it had on a number of occasions and I sort of listened to that which I shouldn't have done, and that was my responsibility because I decide who to listen to and who not to listen to. That's probably my biggest regret.'
} 
Both leaders, Hague and Howard, defended the view that Conservative positions on immigration were close to voters beyond the Conservative core vote, consistent with the data described above, just as William Hague had argued that the Conservative position on Europe was popular with other voters as well as Conservatives. Michael Howard said: 'I thought I was concentrating on the issues that were not of special interest to core Tory voters or any such group but would have been of real interest to the majority of people in the country.'

Howard identified four constraints on his strategy. The one identified specifically was the short time span, eighteen months, during which he was leader. There were three other constraints, the problem of mentioning Iraq and the perception that the issue was not working for Howard (see footnote 82), the problem of Labour's lead on the economy, and the third, a media focus on Howard's position on immigration. It is possible that Conservative strategy was driven off course by media interviews and agendas, and this was argued by Hague in relation to the focus on the euro in 2001. However, it is also possible, of course, that the Conservative campaign generated those expectations, but, if so, their rationale - at least as stated in interviews - was the belief that on these issues they had their greatest relative advantages.

Howard recognized subsequently that perceptual bias was a significant problem in 2005. He remarked:

You know that famous poll which said 'Do you like these policies?' and people say 'Yes' and you say they're the policies of the Conservative party and the approval rating slumps. And I think, you know, that's going to disappear with time and David Cameron's doing a great job in dealing with that problem but it was undoubtedly I think part of the problem in the 2005 election.

Neither Howard nor Duncan Smith arguably had the context or the time to test the potential effectiveness of a new strategy. William Hague faced a Labour party in an extremely strong position, not yet subject to voter antipathy or anger. Iain Duncan Smith's strategy was hampered by continual challenges by colleagues, a series of uncomfortable media appearances, and the challenge to his leadership. Michael Howard was a caretaker leader with just eighteen months to organize a campaign. However, both Hague and Howard conceded there were 'Labour issues' on which they could not win votes and which they were forced to avoid. They both claimed to have focused on the remaining policy areas in which the Conservatives had a relative advantage over Labour, socalled 'Conservative issues', and issues which were considered important to Conservative and other voters alike. Their arguments are supported using the available data on party and voter positions, on issue salience, and on the ratings of the two main parties in Britain on policy issues. Neither leader believed, at the time, that a focus on Conservative issues was electorally damaging, or that these strategies prevented the party from gaining new ground.

According to William Hague, when a government experiences failure on an issue, an opposition party can make headway on it. Figure 3 showed a much wider range of issues on which a new Conservative leader could campaign by 2008, including previous 'Labour issues' such as health and education, and an issue avoided by Michael Howard, the economy. Although the change in issue advantage may have been due to Cameron's popularity, it is plausible that Cameron's focus on issues such as the National Health Service (NHS) and education was also made possible by Labour's falling popularity. Cameron's strategy differed in his avoidance of traditional Conservative strengths. ${ }^{83}$

\footnotetext{
83 Jane Green, 'Strategic Recovery? The Conservatives under David Cameron', in Geddes and Tonge,
} eds, The UK Votes, pp. 85-106. 
That these 'owned' or 'best' issues should have been considered electorally damaging raises many interesting questions for theories of issue salience and ownership. However, Cameron's strategic approach was made easier by the fact that an issue avoidance strategy in 2010 was no longer necessary, in comparison with 2001 (health) and 2005 (the economy).

The data presented in Figures 2 and 3 are consistent with an explanation of party ratings where issue ratings are endogenous to party support. As the Conservatives' support became more positive (negative), their issue ratings did better (worse) over time. This suggests that when parties are popular, they have a broad set of available issues, but when they are unpopular their only available issues are those on which they are traditionally rated most positively. For unpopular parties, therefore, we can propose that parties may appear to fall back on their core issues, where these core issues are traditional party issues (Conservative issues), rather than issues designed to appeal to the core (Conservative) vote. It could even be possible that a party's electoral base represents the only electoral group on which a party could appeal on the broadest issue set. These voters will be more likely to rate their party most positively across the issue agenda, and comprise the only group not to afford ownership to other parties. This contention is supported in a breakdown of 'best party' ratings by vote intention (not reported), particularly in 2001 .

Overall, the arguments point to the importance of the following conceptual distinction: a party's 'owned issues', best issues or in this case 'Conservative issues' are not necessarily the same as 'core vote issues'. To make the assumption that parties have reputations for certain issues, and that their voters automatically care most about these issues, or base their support for their preferred party on the party's position on these issues, appears to be incorrect. The British Conservative party, in 2001 and 2005, focused on issues on which it had a relatively positive rating but these were not, according to the analysis presented, issues to appeal to core Conservative voters alone. When political parties fight election campaigns that appear to be policy-seeking, or that appear to represent appeals to the party base, those parties' strategic decisions can instead be explained by rational votemaximizing objectives.

\section{CONCLUSIONS}

When a candidate or a party's electoral prospects are bleak, in opposition or in government, observers commonly refer to the overriding priority of mobilizing the core vote. Parties undoubtedly need to be concerned with their existing vote base, in times of popularity and in times of defeat. This article has argued that we do not need to rely upon core vote or party base interpretations to understand the electoral strategies of political elites. We can understand the issue strategies and positions of unpopular political parties via long-standing reputations on issues and the changing nature of issue ratings over time. This article has suggested that popular parties, by definition, have a wide range of available issues on which they are rated positively. Less popular parties have only their existing owned or best issues. To focus on traditional issues may mean parties fail to update their image, but these strategies are not driven by an appeal to the issue concerns or positions - of the party base, but by vote-seeking objectives.

The arguments were made on the basis of a range of analyses of the Conservative electoral base, and of Conservative policy positions, together with the self-reported motives of elites. The data failed to support the interpretation that an appeal to 
Conservative voters would necessitate an appeal on right-wing policy positions, that an appeal on the issues of taxation, crime, Europe and immigration would appeal to Conservative voters alone, or that the Conservative party could not appeal to its own voters on Labour's traditional issues, such as the high salience issue in 2001 of the NHS. The Conservatives in opposition wrestled with a trade-off between focusing on issues on which the party was best rated, but which could reinforce its existing image, and issues on which the Labour party was more positively rated, but which were higher in public salience. We need, therefore, to distinguish between a party's 'owned or best issues' and its 'core vote issues'.

This article has also argued for careful conceptualization of the party base via a set of criteria for establishing what is - and what may not be - consistent with a position and emphasis directed at a party's core vote. Scholars commonly refer to base theories, but use activists, members, voters, partisans or the most extreme of these groups to define the base. This article highlights the importance of making clear these distinctions.

The observations made in this article offer implications for candidate and party strategies outside (and within) the context of British politics. The first implication is that partisans or party voters may not explain or lead to the expectation of divergent party policy positions. In the United States, there has been a correlation between elite polarization and increasing partisan alignments, partisan sorting and policy distances between Republican and Democrat partisans. ${ }^{84}$ In Britain, the pattern has moved in the opposite direction. ${ }^{85} \mathrm{We}$ need to study the issue alignments of any country's partisans if we are to relate divergent or convergent elite policy positions to the positions of partisan supporters.

The second implication is that policy transformations may occur without a significant loss of prior electoral support. The British Labour party moderated in the 1990s without incurring large-scale damage to the Labour base and Bill Clinton moved towards the centre in 1992 without losing large segments of Democratic support. Other similar shifts have been observed in Germany and the Netherlands. ${ }^{86}$ David Cameron could reposition the Conservative party (in image if not in large-scale ideological change) without losing the support of the Conservative base. However, parties can push their voters too far. The British Labour party appeared to lose support of its core voters, not following the creation of New Labour under Blair, which was an ideological shift directly in confrontation of the Labour base, but following a difficult period in government and the unpopular Iraq War. Similarly, the Labour party in New Zealand was abandoned by its traditional vote base two elections after changing its social democratic programme in favour of neo-liberal policies. ${ }^{87}$ A greater understanding of party loyalties and tolerances (and their limits and reasons) is needed.

The third implication relates to the nature of party appeals to different voters. We may need to look beyond simple positional and salience appeals to identify subtle tone, class or gendered appeals to 'play to the party base'. The selection of Sarah Palin by John McCain in 2008 was undoubtedly one designed to motivate Republicans (alongside a gendered appeal to prior Hillary Clinton supporters), but her selection did not change McCain's policy positions or the issues identified as those upon which the presidential campaign was focused.

\footnotetext{
84 Joseph Bafumi and Robert Y. Shapiro, 'A New Partisan Voter', Journal of Politics, 71 (2009), 1-24.

85 Adams, Green and Milazzo, 'Has the British Public Depolarized along with Political Elites?'

86 Adam Przeworski and John D. Sprague, Paper Stones: A History of Electoral Socialism (Chicago; London: University of Chicago Press, 1986).

87 Johnston and Pattie, 'Representative Democracy and Electoral Geography'.
} 
Finally, unsuccessful election campaigns need not be interpreted as party base or core vote campaigns. Bob Dole's presidential campaign in 1996, William Hague's general election campaign in 2001 and Michael Foot's Labour campaign in 1983 were all described as being narrowly focused, unsuccessful and orientated towards internal party priorities. While scholars have argued that focusing on a party's owned or best issues may be electorally beneficial, ${ }^{88}$ this may or may not be true when those issues serve to confirm a negative image. To understand these candidates' strategic decisions, we need to appreciate the narrow range of issue advantages these candidates were presented with. In each case, an owned issues campaign may not be synonymous with a core vote issues campaign, and to determine each explanation in each case is an empirical question.

This article urges scholars to reconsider assumptions about the nature of the party base, and of party strategies, in a given country context. It may be misguided to assume that a party that fails to win a majority or to increase its vote share is failing to act in a votemaximizing way. Party strategies so commonly depicted as policy-seeking or as core vote explanations may actually be consistent with vote-seeking rational party objectives and strategies.

APPENDIX

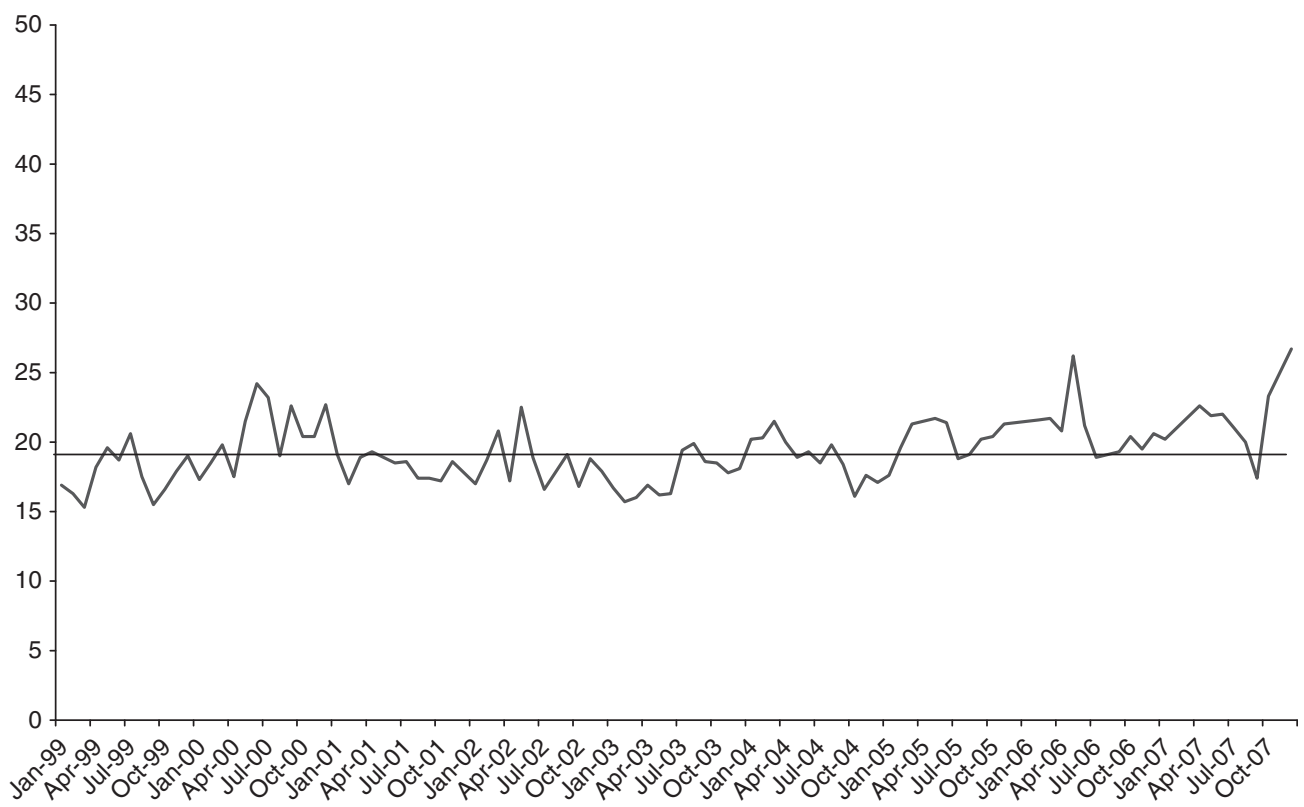

Fig. A1. Conservative vote intention percentages, January 1999-December 2007 Source: Ipsos-MORI.

${ }^{88}$ Budge and Farlie, Voting and Party Competition; Budge and Farlie, Explaining and Predicting Elections; Petrocik, 'Issue Ownership in Presidential Elections'; Petrocik, Benoit and Hansen, 'Issue Ownership and Presidential Campaigning'. 